\title{
Index of names and types of Hoya (Apocynaceae: Asclepiadoideae) of Borneo
}

\author{
M. Rodda \\ Herbarium, Singapore Botanic Gardens, National Parks Board, \\ 1 Cluny Road, Singapore 259569 \\ rodda.michele@gmail.com
}

\begin{abstract}
Types of all Hoya species occurring in Borneo and their synonyms are indicated and clarified. Forty-six lectotypes, nine neotypes and five epitypes are designated.
\end{abstract}

Keywords. Brunei, epitype, holotype, Kalimantan, lectotype, neotype, Sabah, Sarawak

\section{Introduction}

The present paper is a precursor to a revision of Hoya R.Br. of Borneo. Its aim is to list all Hoya taxa occurring on the island of Borneo and their synonyms, clarify and standardize type citation, select lectotypes, epitypes and neotypes when necessary and provide an extensive list of isotypes and syntypes.

The earliest description of a Hoya species that occurs in Borneo, H. multiflora Blume, was described by the German born Dutch botanist Carl Ludwig Blume in 1823, based, however, on Javanese materials. The first Hoya species based on a Bornean collection, H. imperialis Lindl., was published by Lindley (1846). Later, in 1880, Bentham published a peculiar leafless species with long photosynthetic peduncles endemic to Borneo, Astrostemma spartioides Benth. (now Hoya spartioides (Benth.) Kloppenb.). Until 1921 only nine Hoya species where known to occur in Borneo (Merrill, 1921). Nutt (2001) listed 21 species in an unpublished checklist. Lamb et al. (2014) estimated 60-70 species for Sabah alone. In the past 20 years almost 40 taxa (species and subspecies) of Hoya from Borneo have been described, mostly by Ted Green and Dale Kloppenburg (USA). The most recently published taxa have been described predominantly based on collections from Sabah and Sarawak (Rodda \& Simonsson, 2011a, 2011b; Rodda \& Simonsson Juhonewe, 2013a; Lamb et al., 2014; Rodda et al., 2014, 2016; Rodda, 2015a; Lamb \& Rodda, 2016) with only one from Kalimantan (Rahayu et al., 2015).

A guidebook to Hoya R.Br. of Borneo has been recently published (Lamb \& Rodda, 2016) and includes a checklist of Bornean Hoya that lists 72 taxa (71 species and one subspecies) but does not deal with typification of names. The current bibliographic checklist of names is intended as a precursor to a formal taxonomic revision of the genus for Borneo. 


\section{Materials and methods}

The list published here includes accepted names, indicated in bold, of all species occurring in Borneo following the guide book checklist by Lamb \& Rodda (2016: 193-197). All taxa are listed regardless of where the type was collected. Under each accepted name all known synonyms are listed, again regardless of where the type was collected. The protologue of each name has been examined to establish which original materials were listed and needed to be located. Literature was obtained on the Biodiversity Heritage Library website [http://www.biodiversitylibrary.org], JSTOR [http://www.jstor.org/] and in the libraries of the Singapore Botanic Gardens, Royal Botanic Gardens Kew and Royal Botanic Garden Edinburgh.

Types have been located in person or via loans at A, BISH, BM, BO, BRUN, CGE, E, FI, G, HITBC, HN, IBSC, K, KEP, KUN, L, OXF, P, SAN, SAR, SING, SNP, TO, UC, US, VN, WRSL, Z and on JSTOR Global Plants (https://plants.jstor.org/ accessed on 28 July 2016).

If a suitable specimen is available, a lectotype is selected for names where the protologue does not explicitly mention a single type specimen with a direct reference to the institution in which it was deposited, strictly applying Art 9.1 \& 9.2 of the ICN (McNeill et al., 2012). A reference to a single specimen indicated as 'type' or 'holotype' in treatments published before 1 January 2001 is considered as effective lectotypification under Art. 9.9 of the ICN (McNeill et al., 2012). Schlechter's specimens in B are usually considered to be holotypes (Nicholas, 1992). However, for Hoya names this is incorrect under ICN Art. 9.1 (McNeill et al., 2012), as the herbarium where the specimens are deposited is not clearly indicated by Schlechter and it cannot be ascertained that only a single specimen of the type collection was consulted. I have therefore selected lectotypes whenever original material could be located.

Noltie (2005) clarified the type citations of taxa published by Wight. His notation of types is followed here. When based on specimens from Wallich the sheets usually bear a Wallich Asclepiadaceae number (Noltie, 2005), a number assigned to sheets given to Wight from Wallich before Wallich numbers were assigned. These sheets, listed in Linnean Society Manuscript SP1284 became part of Wight's personal working herbarium and bear an HRWP (Herbarium Robert Wight Proper) label and may also bear a Wight number that is often a species number, an 'Asclep' number and the later assigned Wallich number. Sheets from Wight's personal working herbarium are to be considered as Wight's 'top set' (Noltie, 2005: 133), they are often annotated by Wight himself and may have pencilled sketches of the flowers. These specimens are here preferred over other duplicates in the selection of lectotypes. For taxa where a single sheet of a taxon was mentioned in Linn Soc Mss SP1284, if the sheet is extant and can be easily identified, it is considered a holotype. 


\section{Typification of recently published names}

Twenty new Hoya names listed here have been published since 1995 in Fraterna, the bulletin of the International Hoya Society, and two (Hoya ranauensis T.Green \& Kloppenb. and Hoya amoena Bakh.f. subsp. bogorensis T.Green \& Kloppenb.) in the online journal Hoya New (http://www.rare-hoyas.com/publication.htm). As already mentioned by Forster (1991) in relation to taxa from the Philippines published by the same authors, their style of type citation may be confusing as it often includes only a number and the herbarium where the holotype is deposited. Frequently not explicitly referred to a collector, this number may be a sheet number, a collector number or the collection date of the specimen (see Rodda, 2015b). Without a full citation of the holotype, simple citation of a number may refer to multiple specimens belonging to different collectors. This is not strictly needed for valid publication but recommended by ICN Art. 40A.3. (McNeill et al., 2012). I have therefore examined all holotypes or specimens labelled as such in the herbaria where holotypes were deposited, matched them against the protologue and provided a full citation that is corrected in case mistakes were noted in the protologue. Herbarium acronyms followed by a number are here interpreted as sheet number (e.g. UC102003 for Hoya kastbergii Kloppenb.) but may potentially be dates as well (see below $H$. walliniana Kloppenb. \& Nyhuus and $H$. nyhuusiae Kloppenb.). Holotypes of six species have not been found. For three names, Hoya clemensiorum T.Green, $H$. lambii T.Green and $H$. monetteae T.Green, specimens made by the publishing author and labelled as neotypes by him have been found, suggesting that the holotype is indeed missing or was never actually made.

\section{The list of names}

Hoya acicularis T.Green \& Kloppenb., Fraterna 15(4): 7 (2002). - TYPE: Originally from Malaysia, Sabah, Danum Valley, cultivated in USA, Hawaii, Oahu, Ka'a'awa, Green Plant Research, vouchered on 24 January 1991 as Green, T. 93031 (holotype BISH [BISH1000875]).

Hoya aeschynanthoides Schltr., Bot. Jahrb. Syst. 40 (Beibl. 92): 13 (1908). - TYPE: Indonesia, Borneo, Koetei, auf Bäumen am Long Dett, August 1901, Schlechter, R. 13550 (lectotype B [B100277178], designated here).

Notes. Schlechter (1908) mentioned only Schlechter 13550 for Hoya aeschynanthoides Schltr. A single duplicate bearing buds and a drawing of dissected flower parts has been found in B [B100277178] and it is therefore selected here as lectotype of $H$. aeschynanthoides.

Hoya australis R.Br. ex J.Traill, Trans. Hort. Soc. London 7: 28 (1830); Hill, Telopea 3: 250 (1988); Smith, Fl. Vit. Nova 4: 118 (1988); Forster \& Liddle, Austrobaileya 3: 508 (1991); Liddle \& Forster, Asklepios 102: 6(2008). - TYPE: Australia, Queensland, Cook District, Cape Grafton, 1770, Banks, J. \& Solander, D. s.n. (lectotype BM [BM001040528], designated by Hill (1988)). 
Notes. Hoya australis R.Br. ex J.Traill is a widely variable species thought to occur in Australia, Papuasia and Melanesia (Hill, 1988; Forster \& Liddle, 1991; Liddle \& Forster, 2008). It is currently classified into seven subspecies based on vegetative morphology and distribution (Liddle \& Forster 2008; Kloppenburg, 2012). The discovery of Hoya australis in Sabah (based on Jamirus, J. in Lamb, A. AL2500/2014, SAN) considerably extends its distribution area. Preliminary molecular analysis confirms that the Bornean collection belongs to Hoya australis but it is inconclusive to its sub-specific ranking (Rodda, unpublished). This is the reason why synonymies are not indicated here. For the most updated treatment of subspecies and synonymies of Hoya australis see Liddle \& Forster (2008).

The specimen here indicated as lectotype of Hoya australis has long been considered a holotype (Hill, 1988; Smith, 1988; Forster \& Liddle, 1991; Liddle \& Forster, 2008). The specimen is not a holotype as the protologue of Hoya australis is not more specific than that the original material is from Australia in Brown's herbarium. It is therefore impossible to establish whether it was based on a single specimen only. Hill (1988), in mentioning Banks, J. \& Solander, D. s.n. (BM) as holotype of $H$. australis, is here considered as an effective lectotypification following ICN Art. 9.9 (McNeill et al., 2012).

Hoya bakoensis Rodda, Phytokeys 53: 87 (2015) [21 July 2015]. - TYPE: Malaysia, Sarawak, Bako National Park, 20 March 2015, Rodda, M. MR1042b (holotype SING; isotypes SAR, KEP).

Hoya beccarii Rodda \& Simonsson, Webbia 68: 13 (2013). - TYPE: Malaysia, Sarawak, Matang, July 1866, Beccari, O. 1866 (collezioni Beccari 6536a) (holotype FI; isotype FI).

Hoya benchaii Gavrus, A.L.Lamb, Emoi \& Gokusing, Sandakania 19: 18 (2014). TYPE: Originally from Malaysia, Sabah, east of Ranau, Telupid area, cultivated at Kipandi Park, vouchered on 8 May 2011 as Chai, B. in Lamb, A. 2132/2011 (holotype SAN; isotype SNP n.v.).

Hoya callistophylla T.Green, Fraterna 13(4): 2 (2000). - TYPE: Originally from Malaysia, Sabah, Nabawan, cultivated in USA, Hawaii, Oahu, Ka'a'awa, vouchered on unknown date as Green, T. 201 (holotype BISH [BISH1014775]).

Hoya caudata Hook.f., Fl. Brit. India 4(10): 60 (1883); Rintz, Malayan Nat. J. 30: 484 (1978). - TYPE: Peninsular Malaysia, Malacca, Maingay, A.C. 1956 (Kew distr. no. 1128) (lectotype K [K000895134], designated by Rintz (1978), first step, and designated here, second step; isolectotypes K [K000895133], L [L0004315]).

Hoya crassifolia Ridl., J. Straits Branch Roy. Asiat. Soc. 61: 30 (1912), nom. illeg., non Hoya crassifolia (J.Jacq.) Haw. - Hoya caudata Hook.f. var. crassifolia Ridl., Fl. Malay Penins. 3: 395 (1923). - TYPE: Malaysia, Perak, Tapah, on the trees on the Temoh Road, November 1908, Ridley, H.N. 14059 (lectotype SING [SING0059473], designated here; isolectotype K [K001096330]). 
Notes. Hooker indicated the type of Hoya caudata Hook.f. as Maingay 1128. This is the $\mathrm{K}$ distribution number of the Maingay sheets that corresponds to Maingay 1956. The indication by Rintz (1978) of Maingay $1128(\mathrm{~K})$ as 'type' is an effective lectotypification under Art. 9.9 of the ICN (McNeill et al., 2012). However in K there are two sheets labelled Maingay (Kew distr. no. 1128) and, therefore, a second-step lectotypification is necessary. The duplicate with barcode K000895134 is a wellpreserved fertile specimen that also bears a pencilled sketch and is here selected as lectotype of $H$. caudata.

Two duplicates have been found of the type of Hoya crassifolia Ridl. The SING sheet [SING0059473] is a well-preserved fertile specimen and is here selected as lectotype.

Hoya chewiorum A.L.Lamb, Gavrus, Emoi \& Gokusing, Sandakania 19: 25 (2014). - TYPE: Originally from Malaysia, Sabah, Central Crocker Range, Sg. Kopongian on the upper reaches of the Moyong River, cultivated at Kipandi Park, vouchered on 30 April 2009 as Gokusing, L. and Lombika, J. in Lamb, A. AL1769/2009 (holotype SAN; isotype SNP n.v.).

Hoya clemensiorum T.Green, Fraterna 14(3): 12 (2001). - TYPE: Originally from Malaysia, Sabah, Poring, Rafflesia Centre, 16 September 1991, cultivated in USA, Oahu, Ka'a'awa, Hawaii, reputedly vouchered on unknown date as Green, T. 91032 (holotype BISH, missing); Malaysia, Sabah, Mt. Kinabalu, Dallas, 8 Sepember 1931, Clemens, J. \& M.S. 26358 (neotype K, designated here; isoneotypes BM, BO, L).

Notes. The holotype of Hoya clemensiorum T.Green, Green 91032 dated 16 September 1991, cannot be found at BISH. In BISH there is instead a sterile specimen with the same collector and number dated 09 June 2008 labelled as neotype of $H$. clemensiorum, obtained in cultivation from a plant originally wild collected in Sabah on 16 September 1991. I have been unable to find the publication of a neotypification and I therefore select Clemens $26358(\mathrm{~K})$ as the neotype of $H$. clemensiorum as it matches the original description, is fertile, and is among one of the best preserved specimens of $H$. clemensiorum collected by the Clemenses.

Hoya coriacea Blume, Bijdr. Fl. Ned. Ind. 16: 1063 (1826); Rintz, Malayan Nat. J. 30: 495 (1978). - TYPE: Indonesia, Java, Salak [In fruticetis ad pedem montis Salak'], s.d., s.coll. (lectotype L [sheet number 898.168-117], designated here; possible isolectotype $\mathrm{P}[\mathrm{P} 00639838])$.

Hoya brunoniana Wight, Contr. Bot. India 37 (1834). - TYPE: Penang?, Wall Asclep. no 37[= Wall. Cat. 8163] (holotype K; isotypes K [K001129108], E [E00179575]).

Hoya fraterna Blume, Rumphia 4: 32 (1849) [late October 1849]; Blume, Mus. Bot. 1(3): 44 (1849) [November 1849]. - TYPE: Indonesia, Java, West Java, Kuripan [In calcareis Kuripan Javae occidentalis] s.d., s.coll. (lectotype L [L0004318], designated here) (Synonymy established by Backer \& Bakhuizen van den Brink, 1965). 
Hoya occlusa Ridl., J. Straits Branch Roy. Asiat. Soc. 61: 31 (1912). - TYPE: Malaysia, Selangor, top of the Batu Caves, December 1890, Ridley, H.N. s.n. (lectotype SING [SING0059478], designated here).

Hoya angustisepala Elmer ex C.M.Burton, Hoyan 8(4) pt 2: 6 (1987). - Hoya mindanaensis Elmer, Leafl. Philipp. Bot. 10: 3585 (1938), nom. inval. (missing Latin description). - TYPE: Philippines, Davao, Mindanao, Todaya, Mt. Apo, Sibulan River, 3000 ft., June 1909, Elmer, A.D.E. 10829 (lectotype B [B100277215], designated here; isolectotypes BISH [BISH1000876], BM [BM000945404], BO, E [E00288757], K [K000911125], L [L0004313], L(U) [U1102604], NY [NY00318664], US [00170056]).

Notes. Blume did not directly indicate any specimen for Hoya coriacea Blume but mentioned the provenance 'In fruticetis ad pedem montis Salak'. I have located one specimen in L bearing an autograph label by Blume 'Hoya coriacea; Salak' which is, therefore, suitable for designation as the lectotype. A specimen sent by Blume to P in 1836 [P00639838] which is labelled 'In fruticetis ad pedem montis Salak' is a perfect match to Blume's description. However there is no autograph label and therefore the L specimen is preferred as lectotype for $H$. coriacea.

Duplicates of Wall. Asclep. 37[= Wall. Cat. 8163] have been found at E and K. The $\mathrm{K}$ duplicate is the only one bearing a Herbarium Robert Wight Proper (HRWP) label, it is annotated '37 H. brunoniana' has a sketch of the flower in Wight's hand and is therefore one of Wight's specimens on which he based his descriptions. Linn Soc Mss SP1284 indicates that only 1 sheet of Wall. Asclep. 37 was given to Robert Wight for his personal working herbarium, therefore the K sheet can be considered a holotype.

The name Hoya fraterna was first mentioned in volume four of Rumphia (Blume, 1849: 32) [late October 1849] where Blume compared it to the similar species Hoya coriacea (fraterna = brotherly, closely associated (Stearn, 2008)). The description is expanded in Blume (1849: 44) [November 1849] (Stafleu \& Cowan, 1976). Blume did not refer to any specimens but mentioned the provenance as 'In calcareis Kuripan Javae occidentalis'. I have located one specimen in L bearing an autograph label in Blume's hand 'Hoya fraterna $\mathrm{Bl}$; in calcareis Kuripan' that is to be considered original material and is, therefore, selected as lectotype.

One duplicate has been found of the type of Hoya occlusa Ridl. at SING [SING0059478]. The specimen is well-preserved and fertile and is here selected as lectotype.

Hoya coronaria Blume, Bijdr. Fl. Ned. Ind. 16: 1063 (1826); Rintz, Malayan Nat. J. 30: 505 (1978). - Eriostemma coronaria (Blume) Kloppenb. \& Gilding, Fraterna 14(2): 1 (2001). - TYPE: Indonesia, Java, s.d., s.coll. '124/6' (lectotype L, [sheet no. 898.168-121], designated by Kleijn \& Van Donkelaar (2001: 469); isolectotype L [sheet no. 898.168-128].

Eriostemma obtusifolioides Gilding \& T.Green, Fraterna 22(3): 5 (2009). - TYPE: Originally from Malaysia, Sabah, Apin Apin, cultivated in USA, Hawaii, Oahu, Ka'a'awa, Green Plant Research, vouchered in 2007 as Green, T. s.n. (holotype BISH [BISH1072387]). 
=Dischidia villosa nom. nud. (based on L sheet [L0004319, L0004320]).

Notes. Kleijn \& Van Donkelaar (2001: 469) selected sheet no. 898.168-121 (L) as lectotype of Hoya coronaria Blume. This is one of three sheets annotated 'Hoya coronaria Bl' in Blume's hand. It must be noted that both sheet no. 898.168-121 and sheet no. 898.168-128, despite being specimens seen by Blume, cannot be directly linked to the protologue of the taxon. The syntype sheet no. 898.168-124 instead has a label in Blume's handwriting where, among undecipherable words, is the common name 'Kilampahan' and on a different label in Reinwardt's handwriting the possible variant 'Tjilampahan', in agreement with Blume's protologue.

Another syntype of Hoya coronaria is the illustration of Corona Ariadna, published in Rumph. Amb. 5. t. 172.

The synonymy of Hoya coronaria is complex and a taxonomic revision of Hoya section Eriostemma Schltr. is required before a complete list of synonyms can be given. The Bornean Eriostemma obtusifolioides Gilding \& T.Green, however, is indistinguishable from $H$. coronaria so is included here. Eriostemma is nested within Hoya but can be recognised at the sectional level (Hoya sect. Eriostemma) (Wanntorp et al., 2006a, 2006b, 2011, 2014; Rodda \& Ercole, 2014; Rodda et al., 2014). The type of Eriostemma obtusifolioides was only mentioned as 'Bishop 736375 and 'Ex hort. 97048TG, Apinapin, Sabah, Malaysia'. The code '97048TG' was not found on the type sheet. Type citation has been here amended.

Hoya corymbosa Rodda \& Simonsson, Syst. Bot. 38: 1126 (2014). - TYPE: Originally from Malaysia, Sabah, Sipitang District, Mt. Rimau area, cultivated in Kipandi Butterfly Farm, vouchered on 18 June 2009 as Gokusing, L. et al. Al1803/2009 (holotype SAN).

Hoya cumingiana Decne. in A.DC., Prodr. 8: 636 (1844). - TYPE: Philippines, Luzon, Batangas, s.d., Cuming, H. 1480 (lectotype P [P00639839], designated here; isolectotypes BM, C [C10006728], CGE (2 sheets), E [E00288755], G, G-Boiss (2 sheets), K [K001044838, K000911123], L [L0004322]).

Notes. In describing Hoya cumingiana, Decaisne (1844) mentioned a single gathering, Cuming 1480, kept in Delessert's herbarium 'v.s. in herb. Delessert'. Delessert's herbarium was merged into G (Stafleu, 1970) where, however, I could not find any Cuming 1480 specimen clearly labelled as originating from Delessert's herbarium. A suitable specimen from Delessert's herbarium is instead present in P [P00639839], being a well-preserved fertile specimen and is here selected as lectotype for Hoya cumingiana.

Hoya curtisii King \& Gamble, J. Asiat. Soc. Bengal, Pt. 2, Nat. Hist. 74(2): 563 (1908); Rintz, Malayan Nat. J. 30: 505 (1978). - TYPE: Malaysia, Perak, Waterloo, October 1892, Curtis, C. 2894 (lectotype SING [SING0059475], designated here; isolectotypes SING [SING0059474], K [K000895130]). 
Notes. King \& Gamble (1908) described Hoya curtisii based on Curtis 2894. However, they did not mention where their types were deposited and, therefore, a lectotype needs to be selected. Two suitable fertile specimens are present at SING and [SING0059475] is here selected as lectotype.

Hoya danumensis Rodda \& Nyhuus, Webbia 64(2): 164 (2009). - TYPE: Originally from Malaysia, Sabah, Borneo, Danum Valley, January 1993, cultivated in Italy, Turin, vouchered on 3 September 2008 as Rodda, M. 2008.1h (holotype FI; isotypes K, L, TO).

Hoya devogelii Rodda \& Simonsson, Webbia 66(1): 35 (2011) [6 June 2011]. - TYPE: Malaysia, Sarawak, Bahagian Kapit, N. part of Hose Mountains, below ridge leading to Bt. Batu, 10 December 1991, Teck, L.S. and De Vogel, E.F. 9398 (holotype L; isotypes K, SAR n.v.).

Hoya diversifolia Blume, Bijdr. Fl. Ned. Ind. 16: 1064 (1826); Rintz, Malayan Nat. J. 30: 517 (1978); Jagtap \& Singh, Fasc. Fl. India 24: 98 (1999). - TYPE: Rumphius Herbarium Amboinense 5 Tab. 175 Fig. 2. (lectotype, designated here); 'Hoya heterophylla' s.d., s.coll. (epitype L [sheet number 989168-147], designated here).

Hoya heterophylla nom. nud. (based on L sheet number 989168-147).

Hoya crassipes Turcz., Bull. Soc. Imp. Naturalistes Moscou 21: 261 (1848). - TYPE: Indonesia, Java, Zollinger, H. 2581 (lectotype KW [KW001000511], designated here, isolectotype A).

Hoya orbiculata Wall. ex Wight \& Arn. in Wight, Contr. Bot. India 36 (1834). - TYPE: Myanmar, Prome in Ava, 1826, Wallich, N., Wall. Asclep. 32 [= Wall. Cat. 8151] (lectotype K (Herb. R. Wight Proper, with a sketch of the flower in Wight's hand), designated here; isolectotypes E [E00179565], K [K001129088], K 2 more sheets).

Hoya esculenta Tsiang, Sunyatsenia 3: 176 (1936), nom. illeg. - TYPE: Sussuela esculenta Rumph. Herb. Amb. 5: 467, t. 175.28 (1747) (lectotype, designated here).

Hoya zollingeriana Miq., Fl. Ned. Ind. 2: 518 (1857) [20 Aug. 1857]. - TYPE: Indonesia, Java, bij Lalaei, Mei, Zollinger, H. s.n. (lectotype P [P05029459], designated in Rodda (2015b: 306)).

Hoya liangii Tsiang, Sunyatsenia 3(2-3): 177 (1936). - TYPE: China, Hainan, Ngai Yuen, 3 September 1933, Liang, H.Y. 26867 (lectotype IBSC [IBSC0005685], designated here; isolectotype NY [NY00318649]).

Hoya el-nidicus Kloppenb., Fraterna 1991(3) supplement: I (1991). - Hoya diversifolia Blume subsp. el-nidicus (Kloppenb.) Kloppenb., Fraterna 14(1): 13 (2001). - TYPE: Philippines, Palawan, El Nido rest area, 15 August 1988, Pancho, J. s.n. (holotype UPLB sheet no. 41931, n.v.) 
Hoya persicinicoronaria Shao Y.He \& P.T.Li, Novon 19: 475 (2009). - TYPE: China. Hainan Prov., Bawangling, on a tree in montane tropical rainforest, $19^{\circ} 06^{\prime} \mathrm{N} 109^{\circ} 06^{\prime} \mathrm{E}$, 214 m, 8 August. 2007, He, S.Y. \& Lin, J.Y. 0708086 (holotype CANT, n.v., photo at MO not found).

Notes. Blume (1826) indicated in the protologue of Hoya diversifolia a reference to Rumphius' Herbarium Amboinense 5 Tab. 175 Fig. 2 and no direct or indirect reference to a specimen. Rumphius's plate does not have a detailed illustration of the flowers and does not entirely match Blume's description as the leaves, described as 'aveniis' by Blume have evident venation in the plate. However Blume's description may be based on live plants, as fresh leaves do not have distinct venation while veins are sometimes visible in dry specimens. No specimen from Blume's time annotated as collected in 'Kuripan' or 'circa Bataviam' has been found. Herbarium Amboinense 5 Tab. 175 Fig. 2 is therefore the only material available for lectotypification. In L there are numerous specimens identified as Hoya diversifolia with annotations in Blume's hand. Among these there is one labelled Hoya heterophylla in Blume's hand, a nomen nudum, and with a very similar etymology as Hoya diversifolia. Sheet number 989168-147 is a well-preserved fertile specimen and is therefore designated as epitype for Hoya diversifolia. Specimen [P00639841] in P is labelled both Hoya heterophylla and 'Hoya diversifolia Bl. Bijdr' in Blume's (or Decaisne?) hand, the locality is Java, 'm.[isit] Blume 1836' and may be original material, however it is impossible to verify if it was collected prior to 1826 .

Hoya crassipes Turcz. was based on Zollinger 2581. The KW duplicate [KW001000511] is a well-preserved fertile sheet and is designated here as lectotype.

Hoya orbiculata Wall. ex Wight \& Arn. was based on Wall. Asclep. 32 [= Wall. Cat. 8151]. A specimen belonging to what used to be Wight's personal herbarium and bearing a sketch of the flower in Wight's hand is present at $\mathrm{K}$ and is the most suitable lectotype for Hoya orbiculata (Noltie 2005: 134). The plate of Sussuela esculenta in Rumphius (1747: t. 175.28) is a syntype of Hoya orbiculata.

Hoya esculenta Tsiang is an illegitimate name because it is clearly indicated as a synonym of the earlier Hoya diversifolia Blume and Hoya orbiculata Wall. ex Wight $\&$ Arn. and is therefore superfluous and illegitimate following ICN Art. 52.1 (McNeill et al., 2012). It is lectotypified by Herb. Amb. 5: 467, t. 175.28.

The type of Hoya liangii Tsiang was indicated as Liang 26867. The IBSC duplicate [IBSC0005685] is a well-preserved fertile sheet and is designated here as lectotype. The syntype How, C.F. 73935 is also available at IBSC [IBSC0005687]).

Hoya elliptica Hook.f., F1. Brit. India 4: 58 (1883); Rintz, Malayan Nat. J. 30: 505 (1978). - TYPE: Malaysia, Malacca, 1 April 1868, Maingay, A.C. 3286, Kew Distrib. 1137 (lectotype K [K000895126], designated here; isolectotype K [K000895127]).

Notes. Hooker described Hoya elliptica citing specimen Kew Distrib. 1137. Two sheets are preserved at K labelled Kew Distrib. 1137 as well as bearing the original collection number Maingay 3286. The duplicate here selected as lectotype is well preserved, fertile and bears a dissection and a sketch of the flowers by Gamble as an aid to identification. 
Hoya elmeri Merr., Univ. Calif. Publ. Bot. 15: 258 (1929); Rodda et al., Webbia 69: 44 (2014). - TYPE: Malaysia, Sabah, Tawao, October 1922 - March 1923, Elmer, A.D.E. 20652 (lectotype A [A00076433], designated by Rodda et al., (2014: 44); isolectotypes BISH, BM, BO, IBSC, MICH, NY, P, SING, U, UC [UC312114], Z).

Hoya fauziana Rodda, Simonsson \& A.L.Lamb, Webbia 70(2): 207 (2015) [8 June 2015]. - TYPE: Originally from Malaysia, Sabah, Ulu Tomani, $1200 \mathrm{~m}$, cultivated at Kipandi Park, vouchered on 30 October 2013 as Lamb, A. 2462/2013 (holotype SAN; isotype SING).

Hoya finlaysonii Wight, Contr. Bot. India 38 (1834); Rintz, Malayan Nat. J. 30: 511 (1978); Noltie, Bot. Robert Wight 170 (2005). - TYPE: Penang?, herb. Finlayson, Wall Asclep. no 42[B = Wall. Cat. 8166B] (lectotype K [K000895121], designated here; isolectotypes K [K001129114], E [E00179577]).

Notes. The occurrence of Hoya finlaysonii Wight in Borneo is doubtful. However, as numerous closely related taxa occur in Borneo and although their synonymies have not been fully clarified, this name is also typified here. Wight (1834) mentioned the materials for Hoya finlaysonii as 'Wall Asclep. n. 42. Penang?; Wallich and Finlayson'. The description did not include a description of the flowers and it is possible that the specimens examined were all sterile, as also mentioned by King \& Gamble (1908) when referring to Kew's materials of $H$. finlaysonii. A sterile specimen belonging to what used to be Wight's personal herbarium is present at $\mathrm{K}$ and is the most suitable lectotype for Hoya finlaysonii (Noltie 2005: 134). Rintz (1978) mentioned a 'holotype' of Hoya finlaysonii as 'Malaysia, Melaka, Wight (K)' but it is impossible to ascertain whether [K000895121] is the same specimen as no Wight specimen of the taxon was collected in Melaka. Since the specimen is sterile a careful selection of a fertile epitype will be needed. The syntype Wall Asclep. no 42[A = Wall. Cat. $8166 \mathrm{~A}]$ is also present at K [K001129113].

Hoya forbesii King \& Gamble, J. Asiat. Soc. Bengal, Pt. 2, Nat. Hist. 74(2): 574 (1908); Rintz, Malayan Nat. J. 30: 517 (1978). - TYPE: Indonesia, Sumatra, Kaba Volcano, 1881, Forbes, H.O. 2896 a (lectotype K [K000894730], designated here).

Notes. Three specimens were cited in the original description of Hoya forbesii, Scortechini 1679 \& 1680 and Forbes 2896a. The only extant specimen I was able to locate is Forbes $2896 a(\mathrm{~K})$, which also bears a dissection and a drawing of the flowers in Gamble's hand and is therefore selected as the lectotype.

Hoya gildingii Kloppenb., Fraterna 15(1): 10 (2002). - TYPE: Originally from Malaysia, Sabah, Mt. Kinabalu, Bukit Tapai Trail, cultivated in Sweden, vouchered in 2001 as Wiberg, E.K., s.n. (holotype UC [UC1784972]).

Hoya glabra Schltr., Bot. Jahrb. Syst. 40 (Beibl. 92): 14 (1908). - TYPE: Borneo, Long Wahau, 2 Aug 1901, Schlechter, R. 13458 (lectotype B [B100277199], designated here). 
Notes. Schlechter 13458 is extant in B and is therefore selected as lectotype for Hoya glabra.

Hoya hamiltoniorum A.L.Lamb, Gavrus, Emoi \& Gokusing, Sandakania 19: 32 (2014). - TYPE: Originally from Malaysia, Sabah, Ulu Tomani, cultivated at Kipandi Park, vouchered on 26 Aug 2009 as Gokusing, L. \& Lombika, J. in Lamb, A. 1814/2009 (holotype SAN; isotype SNP n.v.).

Hoya ignorata T.B.Tran, Rodda, Simonsson \& Joongku Lee, Novon 21(4): 509 (2011) [29 December 2011]. - TYPE: Vietnam. Dak Lak, Dak Mil, 11 December 1979, Bien, L. K. 1072 (holotype HN; isotype MO).

Hiepia corymbosa V.T.Pham \& Aver., Turczaninowia 14(3): 6 (2011). - TYPE: Vietnam, Quang Tri prov., Da Krong distr., Ta Rut municipality, A Pul village, around point $16^{\circ} 24^{\prime} 29^{\prime \prime} \mathrm{N} 107^{\circ} 01^{\prime} 07^{\prime \prime} \mathrm{E}$, broad- leaved evergreen forest along rocky river canyon composed with shale and sandstone at elev. about $300 \mathrm{~m}$ a.s.1., 10 May 2011, Averyanov, L., Loc, P.K., Hieu, N.Q., The, P.V., Vinh. N.T. CPC 3066 (holotype Herbarium of the Center for Plant Conservation, Vietnam, n.v.; isotype LE, n.v.).

Notes. The monotypic genus Hiepia V.T.Pham \& Aver. was published on 28 September 2011. Examination of the protologue, associated images and detailed photographs of the taxon (Pham \& Averyanov, pers. comm.) suggest that it is indistinguishable from a taxon published as Hoya ignorata T.B.Tran et al. on 29 December 2011. Rodda et al. (2014) showed that the taxon belongs to the genus Hoya and since the epithet 'corymbosa' is unavailable in Hoya the correct name is Hoya ignorata under Art. 11.4 of the ICN (McNeill et al., 2012).

Hoya imperialis Lindl., Edwards's Bot. Reg. 32: sub. t. 68 (1846); Rintz, Malayan Nat. J. 30: 501 (1978); Forster \& Liddle, Asklepios 56: 24 1992). - TYPE: Herb. Lindley 'Cultivated, from Sarawak via Lowe's Nursery', s.d., s.coll., s.n. (lectotype CGE [CGE06041], designated here).

Hoya imperialis Lindl. var. rauschii Regel, Gartenflora 282 (1855). -TYPE: Gartenflora 1855: 282. t.134 (erroneously numbered t.130) (lectotype designated here).

Notes. Forster \& Liddle (1992a) mentioned that a lectotype for Hoya imperialis Lindl. may have to be chosen from one of the illustrations published by Lindley (however no illustration was provided together with the protologue) as no type specimen may be extant in BM, K or L (Rintz, 1978). Lucas (2008) traces the Lindley herbarium to CGE. There I have found a specimen originally belonging to Lindley's herbarium that is here selected as lectotype for Hoya imperialis.

Hoya imperialis Lindl. var. rauschii was described as having paler corolla lobes than the type. The taxon was described from cultivated material growing in Schaffhausen (Switzerland). Original material has not been found and it is possible that a specimen was never made. The illustration published concurrently with the description is selected as lectotype. 
Hoya jiewhoeana Rodda, A.L.Lamb \& Gokusing, Guide Hoyas Borneo 198 (2016) [2 May 2016] (as 'jiewhoeiana'). - TYPE: Originally from Malaysia, Sabah, Tawau, Kalabakan area, local collector, cultivated in Sabah, vouchered on 17 January 2016 as Bosuang, S. \& Gokusing, L. in Lamb, A. AL2747/2016 (holotype SAN; isotype SING).

Hoya kastbergii Kloppenb., Fraterna 16(4): 1 (2003). - TYPE: Malaysia, Sarawak, Bau, Kastberg, A. (holotype UC, missing). Malaysia, Sarawak, Near Mulu National Park H.Q., 23 March 1981, Collenette, I.S. 2357 (neotype L [L2726571], designated here; isoneotype $\mathrm{K}$ ).

Notes. The type specimen of Hoya kastbergii was indicated only as 'UC102003'. The specimen in UC barcoded [UC102003] belongs to Erigeron glacialis (Nutt.) A. Nelson var. glacialis (Pia Nutt pers. comm.). It is possible that '102003' may be a collection date (October 2003) and not a barcode. See Hoya nyhuusiae below for a similar case. No other specimen of Hoya kastbergii is present in UC and since no collection information apart from the collector name and the UC barcode was provided in the description of the taxon it is impossible to identify isotypes that may be present in other herbaria. To fix the application of the name I have therefore selected another specimen matching the original description, Collenette 2357 (L) as neotype of $H$. kastbergii.

Hoya kipandiensis Gavrus, A.L.Lamb, Emoi \& Gokusing, Sandakania 19: 42 (2014). - TYPE: Originally from Malaysia, Sabah, central Crocker Range, Mongkusilad River, nr. Kg. Kipandi, cultivated at Kipandi Park, vouchered on 25 Jan 2010 as Gokusing, L. in Lamb, A. 1909/2010 (holotype SAN; isotype SNP n.v.).

Hoya kloppenburgii T.Green, Fraterna 14(2): 11 (2001). - TYPE: Originally from Malaysia, Sabah, Nabawan, cultivated in USA, Hawaii, Oahu, Ka'a'awa, vouchered on unknown date as Green, T. 97057 (holotype BISH [BISH1014779]).

Hoya lacunosa Blume, Bijdr. Fl. Ned. Ind. 16: 1063 (1826); Rintz, Malayan Nat. J. 30: 490 (1978). - Otostemma lacunosum (Blume) Blume, Rumphia 4: 30 (1849) [late October 1849]. - TYPE: [circa Buitenzorg at arbores] Hoya lacunosa, s.d., s.coll., s.n. (lectotype L [sheet number 898168-188], designated here).

Notes. The only specimen belonging to Hoya lacunosa Blume that can be referred to Blume is sheet number 898168-188 (L) that bears an autograph label 'Hoya lacunosa'. Blume left Java in 1826 and returned to the Netherlands (Van Steenis-Kruseman, 1950). Therefore the specimen, if collected by Blume, is likely to have been collected before the publication of the Asclepiadaceae account in the Bijdragen (Blume, 1826) and is therefore a suitable lectotype for Hoya lacunosa.

Hoya lambii T.Green, Fraterna 13(2): 2 (2000). - TYPE: Originally from Malaysia, Sabah, cultivated in USA, Hawaii, Oahu, Ka'a'awa, reputedly vouchered on unknown date as Green, T. 9905 (holotype BISH, not found). Originally from Malaysia, Sabah, 
Cultivated in USA, Hawaii, Oahu, Ka'a'awa, vouchered on unknown date as Green, T. s.n. (neotype BISH [BISH1016619], designated here).

Notes: The holotype of Hoya lambii, Green 9905 is not present in BISH and no duplicates have been located in other herbaria. A specimen labelled as neotype is present in BISH (Green s.n.) suggesting that the publishing author may be aware that the holotype is missing. However, the neotypification has not been published and is therefore formally published here.

Hoya lasiantha (Korth. ex Blume) Miq., Fl. Ned. Ind. 2: 526 (1857) [20 August 1857]; Rintz, Malayan Nat. J. 30: 498 (1978). - Plocostemma lasianthum Korth ex Blume, Mus. Bot. 1(4): 60 (1849). - TYPE: Borneo, [ad montem Pamotton insulae Borneo] s.d., Korthals, P. s.n. (lectotype U [U1102625] designated here); Mus. Bot. 1(4) Fig. 14 (1849) (epitype, designated here).

Notes. The name Hoya lasiantha is usually attributed to Blume (1849: 30) [late October 1849] (Stafleu \& Cowan, 1976) where it is, however, a nomen nudum as it refers only to a specimen labelled Hoya lasiantha in Korthals herbarium. The taxon is validated as Plocostemma lasianthum Korth. ex Blume (Blume 1849: 60) [November 1849] (Stafleu \& Cowan, 1976) and later transferred to Hoya by Miquel (1857). The authorship of the name is here corrected.

Blume mentioned a collection in Korthals herbarium from Borneo 'ad montem Pamotton insulae Borneo'. I have located a single specimen matching Blume's description and illustration (Blume, 1849: Fig. 14) with a manuscript annotation by Korthals 'Hoya lasiantha Borneo' in L (formerly in U). The label does not have further details on the collection locality, but this is common with Korthals specimens (Van Steenis-Kruseman, 1950). The specimen is only a fragment with a single mounted flower. It is possible that an original complete specimen was in L but may have gone missing, or that Korthal's label may have been mixed during Miquel's time (Van Steenis-Kruseman, 1950), therefore the U specimen is the only available original material for lectotypifying Hoya lasiantha. To aid in the application of the name the detailed illustration in Blume (1849, Fig. 14) is selected as epitype.

Hoya latifolia G.Don, Gen. Hist. 4: 127 (1837); Rintz, Malayan Nat. J. 30: 508 (1978). - Hoya macrophylla Wight, Contr. Bot. India 38 (1834), non Hoya macrophylla Blume (1826). - TYPE: Malaysia, Penang, Wall. Asclep. no. 138[A = Wall. Cat 8161A (lectotype K [K000895124], designated here) ex parte; isolectotypes CGE (1 not mixed, 1 ex parte, E [E00179576], K [K000895125].

Notes. A suitable lectotype for Hoya latifolia G.Don can be selected from amongst material of the two syntypes indicated in the protologue (Wall. Asclep. no. 138[A $=$ Wall. Cat 8161A] and Wall. Asclep. no. 138[B = Wall. Cat 8161B]). Original specimens have been found at CGE, E and $\mathrm{K}$. The one here selected as lectotype is the only one bearing a Herbarium Robert Wight Proper (HRWP) label indicating that it was one of the specimens studied by Wight and on which he based his descriptions 
(Noltie, 2005). The specimen is composed of two leaves and a follicle, excluding the flowers in the envelope, which belong to Hoya mitrata Kerr (Rodda, 2012). Often two types of leaves are present on each specimen, some agreeing with Wight description (palminerved) others easily separated because they are penninerved and with a thinner texture. As suggested by Nutt (label on [K000895124]), the flowers do not agree with H. latifolia as currently applied e.g. in Rintz (1978). A syntype Wall. Asclep. no. 138[B $=$ Wall. Cat. 8165B] is present at K [K000895123].

Hoya mappigera Rodda \& Simonsson, Feddes Repert. 122(5-6): 338 (2012). - TYPE: Malaysia, Dingdings, Lumut Dindings, 1894, Ridley, H.N. s.n. (holotype SING [SING0120871]).

Hoya medinillifolia Rodda \& Simonsson, Webbia 66: 149 (2011). - TYPE: Malaysia, Sarawak, Batu Laga Plateau, Batang Rejang, $7^{\text {th }}$ Division, 10 Sep 1984, Abang Mohtar S.48205 (holotype K [K000894726]; isotypes L, SAR).

Hoya meredithii T.Green, Fraterna 20(3): 14 (2007). - Hoya meredithii T.Green, Phytologia 64(4): 304 (1988), nom. inval. - TYPE: Originally from Malaysia, Sarawak, Bau, Meredith, Y. 80-05, cultivated in USA. Hawaii, Oahu, Ka'a'awa, vouchered in 1981 as Green, T. 81-002 (holotype BISH [BISH1014780]; isotypes BISH [BISH1014781], NY).

Notes. The holotype of Hoya meredithii T.Green was cited by Green (2007) as 'Bishop Museum, 511439 hic designatus, ex hort, T. Green of Oahu, Kaaawa, Hawaii, Lectotype (NY)'. This is interpreted as holotype BISH [BISH1014780], with an isotype at NY. A second isotype at BISH [BISH1014781] is present.

Hoya mindorensis Schltr., Philipp. J. Sci. 1 (Suppl. 4): 303 (1906). - TYPE: Philippines, Mindoro, Baco River, April-May 1905, McGregor, R.C. 332 (lectotype B [B100277216], designated by Rodda et al. (2014)).

Hoya minutiflora Rodda \& Simonsson, Webbia 65(2): 174 (2010). - TYPE: Originally from Borneo?, cultivated at Hortus Botanicus Leiden., vouchered in August 1999 as $S$. coll. L30929, IPPS 7760 (holotype L, spirit material).

Hoya mitrata Kerr, Hooker's Icon. P1. 35. t. 3406 (1940). - TYPE: Thailand, Surat, Ban Tong Tao, Kerr, A.F.G. 13152 (lectotype K, designated by Rintz (1978)).

Hoya wallichiana Decne. inA.DC., Prodr. 8: 635 (1844) nom. rej. prop. - TYPE: [Malaysia, Penang] "Hoya Wallichiana Dne in DC. Prodr. Hoya coronaria Bl. (d'apres Hooker Fl. of British India IV 58)" (lectotype P designated in Rodda (2012)).

Notes. A lectotype was selected in Rodda (2012). However, Rintz (1978) mentioned the same specimen and used the word 'type' which counts as an earlier lectotypification under Art. 9.9 of the ICN (McNeill et al., 2012). Hoya mitrata has been proposed 
as a nom. cons. prop. against the earlier Hoya wallichiana Decne. (Rodda, 2012). A decision is still pending.

Hoya monetteae T.Green, Fraterna 17(2): 10 (2004). - TYPE: Philippines, Palawan Island, Tumarbong River delta, 4 November 2000, Green, T. 007 (holotype BISH, not found). Malaysia, Sabah, Lahad Datu, Tabin, South Eastern Trail, 3-4 km from the base camp, 100-200 m, 10 March 1998, Sugau, J.B., et al. JBS340 (neotype SAN, designated here; isoneotypes K, L [L2718278]).

Notes. The specimen Green 007, dated 4 November 2000, is not extant in BISH. A sterile specimen, Green 007, dated 30 May 2008, labelled as neotype of Hoya monetteae is instead present at BISH. I have been unable to find publication of the neotypification. Specimen Sugau et al. JBS340 (SAN) is a fertile and well-preserved specimen of $H$. monetteae and is here selected as a neotype.

Hoya multiflora Blume, Cat. Gew. Buitenzorg 49 (1823); Rintz, Malayan Nat. J. 30: 492 (1978); Jagtap \& Singh, Fasc. Fl. India 24: 108 (1999). - Centrostemma multiflorum (Blume) Decne., Ann. Sci. Nat., Bot. sér. 2, 9: 272 (1838). - Cyrtoceras multiflorum (Blume) Heynh., Nom. Bot. Hort. 1(2): 183 (1840). - TYPE: Indonesia, Java [prope flumine Tjapaes? Kietpil?, Salleh], 16 Sep 1820, s.coll., s. num. (lectotype L [L2727033], designated here).

Asclepias carnosa Blanco, Fl. Filip. 208 (1837), non L.f. (1782). - TYPE: Philippines, Rizal Province, Luzon, Bosoboso, March 1915, Merrill Species Blancoanae 852 (neotype L [L2726976], designated here; isoneotype P [P00700474]).

Cyrtoceras reflexum Benn., Pl. Jav. Rar. 90 (1838). - Centrostemma cyrtoceras (Benn.) Meisn., Pl. Vasc. Gen. 177 (1840), nom. inv. - TYPE: Indonesia, Java, Bennett, P1. Jav. Rar. (1838) Fig. 21 (lectotype, designated here). Indonesia, Java, 'Ascl. 5' 1802-1818, Horsfield, T. s.n. (epitype K [K000894745], designated here; isoepitype K).

Cyrtoceras lindleyanum Decne. Hort. Universel 1: 81 (1839). - Hoya coriacea auct. non Blume: Lindley, Edwards’s Bot. Reg. 25: t.18 (1839). - Centrostemma coriaceum Meisn., Pl. Vasc. Gen. 177 (1840), nom. illeg. - Centrostemma lindleyanum (Decne.) Decne. in A.DC., Prodr. 8: 634 (1844). - Cyrtoceras coriaceum Heynh., Nom. Bot. Hort. I (2): 183 (1840), nom. illeg. - TYPE: Philippines, Manila, cultivated in UK, Loddiges Nurseries, August 1830? (lectotype CGE [CGE06040], designated here).

Cyrtoceras floribundum Maund, Botanist 4: t. 178 (1840), nom. illeg. - TYPE: Maund, Botanist 4: t. 178 (1840) (lectotype, designated here).

Centrostemma micranthum Blume, Mus. Bot. 1(3): 46(1849).-Cyrtoceras micranthum (Blume) Miq., Fl. Ned. Ind. 2: 515 (1857). - Hoya celebica Boerl., Handl. Fl. Ned. Ind. 2: 440 (1899). - TYPE: 'in sylvis insulae Celebes’ Fig. 12 in Blume, Mus. Bot. 1(3) (1849) (lectotype, designated here). 
Centrostemma elegans Blume, Mus. Bot. 1(3): 46 (1849). - Cyrtoceras elegans (Blume) Miq., Fl. Ned. Ind. 2: 515 (1857). - Hoya elegans (Blume) Boerl., Handl. F1. Ned. Ind. 2: 440 (1899), non Kostel. (1834). - TYPE: Borneo, s.d, s.coll, s.n. (lectotype L [L2726969], designated here).

Centrostemma laurifolium Blume, Mus. Bot. 1(3): 46 (1849). - Cyrtoceras laurifolium (Blume) Miq., Fl. Ned. Ind. 2: 514 (1857). - Hoya javanica Boerl., Handl. Fl. Ned. Ind. 2: 440 (1899). - TYPE: Indonesia, Java, W Java [Tjunkankan. In sylvis montanis Javae occidentalis], Salak, August 1825, s.coll., s.n. (lectotype L [L0004337], designated here).

Cyrtoceras uncinatum Teijsm. \& Binn., Natuurk. Tijdschr. Ned.-Indië 25: 408 (1863). - TYPE: Indonesia, Sumatra, Palembang, ad arbores, s.d., Teijsmann, J.E. (not found). Indonesia, Java [prope flumine Tjapaes? Kietpil?, Salleh], 16 Sep 1820, s.coll., s. n. (neotype L [L2727033], designated here).

Hoya reticulata Costantin in Lecomte, Fl. Indo-Chine 4: 138 (1912), non Hoya reticulata Moon (1824), nec Hoya reticulata Schltr. (1913), nec Hoya reticulata Merr. (1921). - TYPE: Cambodia, Mt. Krewanh, Sep 1870?, Pierre, L., s.n. (lectotype P [P00700502], designated here).

Centrostemma platypetalum Merr., Sunyatsenia 2: 16-17 (1934). - TYPE: China. Guangdong. Sup Man Ta Shan, 19 July 1933, Tso, C.L. 23346 (lectotype NY [NY00318540], designated here).

Hoya refracta nom. nud. on numerous sheets in L and $\mathrm{P}$.

Notes. The publication of Hoya multiflora Blume only consists of a diagnosis 'caule fruticoso scandente; foliis oppositis oblong-lanceolatis utrinque acutis glabris subtus pallidioribus; floribus fasciculatis terminalibus' without any information that could link it to a specimen such as a collector name, a locality or a common name. Numerous specimens of Hoya multiflora are present in L with Blume's autograph labels. Among these, only one [L2727033] has a date definitively setting its collection before publication of the protologue, ' 16 September 1820'. It is a fertile and well-preserved specimen and is therefore suitable lectotype material.

There are no known extant collections from Blanco, including for Asclepias carnosa Blanco, non L.f. (Merrill, 1918). Merrill's illustrative specimen 852 is therefore selected as neotype for Asclepias carnosa Blanco.

No specimens are listed for Cyrtoceras reflexum Benn. The plate included together with the species description (Bennett, 1838 Fig. 21) is therefore selected as lectotype. A Horsfield collection from Java [K000894745] that may be original material is selected as an epitype.

Cyrtoceras lindleyanum Decne. was a new name based on a plant misidentified by Lindley as Hoya coriacea Blume (Lindley, 1839). Lindley's treatment was based on a plant 'Sent by Mr Cuming to Messrs. Loddiges, from Manila; it flowered for 
the first time in August 1838'. In Lindley's herbarium at CGE there is a sheet labeled 'Hoya coriacea Loddiges Aug. 1830'. Excluding the date that does not match, this sheet matches the protologue and being the only original material available is here selected as lectotype for Cyrtoceras lindleyanum. Miquel (1857: 515) cited Cyrtoceras lindleyanum Miq. with himself as the author. This, however, is likely a typographical error as he clearly also included Cyrtoceras lindleyanum Decne. in the citation.

Cyrtoceras floribundum is clearly indicated as a synonym of the earlier Cyrtoceras reflexum Benn. and is therefore superfluous and illegitimate following ICN Art. 52.1 (McNeill et al., 2012). The name was based, as per Hoya coriacea Lindl., on a live plant originally collected by Cuming in the Philippines and cultivated at Loddiges Nursery (UK). No specimens have been found with such provenance. The only material available for the selection of a lectotype is therefore the plate included together with the species description.

No specimens are mentioned for Centrostemma micranthum Blume. The illustration published concurrently with the description is therefore selected as the lectotype.

No specimens are mentioned for Centrostemma elegans Blume. There is, however, a specimen in L identified as Centrostemma elegans in Blume's handwriting, also labelled Cyrtoceras elegans (Blume) Miq in Miquel's hand and Hoya elegans (Blume) Boerl. in Boerlage's hand, that is a suitable lectotype.

No specimen was mentioned in the description of Centrostemma laurifolium, only 'In sylvis montanis Javae occidentalis.' A specimen bearing a label in Blume's hand from Salak is here selected as lectotype.

Cyrtoceras uncinatum Teijsm. \& Binn. was described from plants cultivated in Bogor Botanic Garden originally collected from Sumatra by Teijsmann. No specimens have been found and it is possible that the description was based on a live plant. The name is neotypified with the lectotype of Hoya multiflora.

In P herbarium there is only one specimen labeled in Costantin's hand as Hoya reticulata Costantin, collected by Pierre on Mt. Krewanh. This specimen [P00700502] is therefore selected as lectotype.

Centrostemma platypetalum Merr. was described based on Tso 23346. The NY duplicate is a fertile well-preserved specimen and is here selected as lectotype.

Hoya nabawanensis Kloppenb. \& Wiberg, Fraterna 15(2): 2 (2002). - TYPE: Originally from Malaysia, Sabah, Nabawan, cultivated in Sweden, Borlänge, vouchered on unknown date (before March 2002), as Wiberg, E.K. s.n. (holotype UC [UC1776376]).

Hoya nuttiana Rodda \& Simonsson, Phytotaxa 140: 56 (2013). - TYPE: Malaysia, Sarawak, near Kuching, 24 October 1894, Haviland, G.D. \& Hose, G.F. 8530 (holotype K [K000014447]).

Hoya nyhuusiae Kloppenb., Fraterna 16(3): 1 (2003). - TYPE: Originally from Malaysia, Sabah, Mt. Kinabalu, cultivated in Sweden, Stockholm, vouchered in 2003 as Nyhuus, T. s.n. (holotype UC [UC1784974]). 
Notes. The protologue of Hoya nyhuusiae Kloppenb. states ‘(UC) Torill Nyhuus \#2003 ex hort. Torill Nyhuus, Sweden. From Mt. Kinabalu, Sabah, Malaysia'. There is no specimen Nyhuus 2003 in UC but the specimen labelled as holotype is Nyhuus s.n. and '2003' is the year of collection as also noted for Hoya walliniana. Type citation has been amended accordingly.

Hoya obscura Elmer ex C.M.Burton, Hoyan 8(1): 15 (1986). - Hoya obscura Elmer, Leafl. Philipp. Bot. 10: 3586 (1938), nom. inval. (missing Latin description). - TYPE: Philippines, Luzon, Sorsogon, Irosin, Mt. Bulusan, July 1906, Elmer, A.D.E. 16719 (lectotype US [US00026729], designated here; isolectotypes BISH [BISH1000882], $\mathrm{BM}$ [BM000945396], BO, G, GH, K [K000911128], L [L0004338], L(U) [U1102639], NY [NY00318665], P [P00639850], S [S12-12728], UC [UC272655], US [US00026729]). Philippines, Luzon, Nueva Vizcaya, vicinity of Dupax, MarchApril 1912, McGregor, R.C., 11377 (epitype BM [BM001135048], designated here).

Notes. No single holotype of Hoya obscura Elmer ex C.M.Burton was stated by Burton and a lectotype needs to be designated among the duplicates of the type collection Elmer 16719. All duplicates located and examined are sterile and a selection of an epitype is necessary for a correct application of the name. Specimen McGregor 11377, a fertile and well-preserved specimen is therefore selected as epitype of H. obscura.

Hoya obtusifolia Wight, Contr. Bot. India 38 (1834); Rintz, Malayan Nat. J. 30: 520 (1978); Jagtap \& Singh, Fasc. Fl. India 24: 113 (1999); Noltie, Bot. Robert Wight 170 (2005). - TYPE: sin. loc. (Malaysia, Penang?), Wallich, Wall. Asclep. 38 [= Wall. Cat. 8167] (holotype K [K000895115]; isotypes E [E00179578], K [K001129115]).

Hoya teysmanniana Miq., F1. Ned. Ind. 2: 522 (1857). - TYPE: Indonesia, Sumatra, Soengi Pagoe, s.d., Teijsmann, J.E., $1170 H B$ (lectotype U [U0000686], designated here; possible isolectotype K [K000894744]).

Notes. Duplicates of Wall. Asclep. 38[= Wall. Cat. 8167] have been found at E and K. The K duplicate is the only one bearing a Herbarium Robert Wight Proper (HRWP) label, it is annotated '38 Hoya obtusifolia RW', and is therefore one of Wight's specimens on which he based his descriptions. Linn Soc Mss SP1284 indicates that only 1 sheet of Wall. Asclep. 38 was given to Robert Wight for his personal working herbarium, therefore the K sheet can be considered a holotype.

Hoya teysmanniana Miq. was described from Teijsmann material indicated as being from 'Sumatra, bij Soengi Pagoe'. The U specimen [U0000686] is the only one found which matches this information and is therefore selected as lectotype. The $\mathrm{K}$ specimen [K000894744] was also collected by Teijsmann in Sumatra and bears a label in Miquel's hand. However, it does not have a collection number or locality (Sumatra only) and may be considered as a possible isolectotype.

Hoya omlorii (Livsh. \& Meve) L.Wanntorp \& Meve, Willdenowia 41(1): 99 (2011) [Jun 2011]. - Clemensiella omlorii Livsh. \& Meve, Edinburgh J. Bot. 66: 454 (2009) 
('omlori'). - TYPE: Indonesia, Sumatra, Aceh, Gunung Leuser Reserve, Camp Simpang and vicinity, 19 August 1972, de Wilde, W.J.J.O \& de Wilde-Duyfjes, B.E.E. 14377 (holotype L; isotype K).

Hoya pubera Blume, Bijdr. Fl. Ned. Ind. 16: 1065 (1826). - Acanthostemma puberum Blume, Rumphia 4: 29 (1849). - TYPE: [in maritimis insulae Nusae Kambangae ad arbores] (lectotype L [L0275692], designated here).

Notes. A few specimens can be found in L labelled Hoya pubera Blume. Among these, [L0275692] bears a label, likely in Blume's hand, with '1684 Dischidia elliptica Bl. Hoya pubera Bl.' another specimen [L0275693] bears 'Acanthostemma pubera Bl, Hoya pubera Bl (illegible) Bl. 1684', possibly in Blume's hand. Both are sterile and cannot without doubt be linked to the protologue of Hoya pubera. Another specimen, in P [P00639851], was sent by Blume as Hoya pubera in 1836 and mentioned by Decaisne (1844: 639). Once again this is sterile and it is impossible to ascertain whether it was collected before the publication of $H$. pubera. Another specimen in $\mathrm{U}$ [U1102645] is labelled as collected by Blume, but is undated and just a fragment. Following Art. 9.12 of the ICN (McNeill et al., 2012), [L0275692] is to be considered as 'remaining original material' and is therefore here selected as the lectotype for Hoya pubera.

Hoya phyllura O.Schwartz, Mitt. Inst. Bot. Hamburg 7: 26 (1931). - TYPE: Indonesia, Borneo, Lebang Hara, 24. November 1924, Winkler, H. 339 (lectotype HGB [HBG506353], designated here; isolectotype HBG [HBG506354]).

Hoya linusii A.L.Lamb, Gavrus \& Emoi, Sandakania 19: 50 (2014) [2 May 2014] .TYPE: Originally from Malaysia, Sabah, Crocker Range, upper reaches of the Moyog River, cultivated at Kipandi Park, vouchered on 13 November 2007 as Gokusing, L in Lamb, A. 1223/2007 (holotype SAN; isotype SNP, n.v.).

Notes. Schwartz cited only a single collection for Hoya phyllura, Winkler 339. Two duplicates are found in HBG. The first, bearing a sketch of the flowers is selected as the lectotype.

Hoya ranauensis T.Green \& Kloppenb., Hoya New 2(3): 21 (2014) [before 22 May 2014].-TYPE: Originally from Malaysia, Sabah, Ranau, Poring Hot Springs, cultivated in USA, Hawaii, Oahu, Ka'a'awa, garden of Ted Green, vouchered on unknown date as Green, T. s.n. (holotype BISH, sheet no. BISH757786 [BISH1049135]).

Hoya retrorsa Gavrus, A.L.Lamb, Emoi \& Gokusing, Sandakania 19: 59 (2014). TYPE: Originally from Malaysia, Sabah, Pensiangan, Mount Lumatan, cultivated at Kipandi Park, vouchered on 4 May 2010 as Gokusing, L. in Lamb, A. 1950/2010 (holotype SAN; isotype SNP n.v.). 
Hoya revoluta Wight ex Hook.f., Fl. Brit. India 4: 55 (1883). - TYPE: Malaysia, s.1., s.d., Maingay, A.C. 1127 (lectotype K [K000279860], designated by Forster \& Liddle (1992b)). Malaysia, Pahang, Tasek Bera, low altitude, 14 October 1930, Henderson, M.R. 24439 (epitype SING, designated by Rodda \& Simonsson Juhonewe (2013b)).

Hoya rintzii Rodda, Simonsson \& S.Rahayu, Webbia 69: 44 (2014). - TYPE: Malaysia, Selangor, Sungai Langat, 3 Jun 1976, Rintz, R.E. RER61 (holotype KEP; isotype K).

Hoya rundumensis (T.Green) Rodda \& Simonsson, Webbia 68: 13 (2013). - Hoya plicata King \& Gamble subsp. rundumensis T.Green, Asklepios 108: 19 (2010). TYPE: Originally from Malaysia, Sabah, Rundum, $3000 \mathrm{ft}$., cultivated in USA, Oahu, Ka'a'awa, Hawaii, garden of Ted Green, vouchered on 12 August 2009 as Green, T. 2010.001 (holotype BISH [BISH1016412]).

Hoya ruthiae Rodda, Phytokeys 53: 84 (2015) [21 July 2015]. - TYPE: Malaysia, Sabah, Lahad Datu, Bukit Baturong, on limestone, 7 July 2000, Kiew, R. RK5029 (holotype SING [SING0077484]).

Hoya scortechinii King \& Gamble, J. Asiat. Soc. Bengal, Pt. 2, Nat. Hist. 74: 567 (1908) [20 February 1908] - TYPE: Malaysia, Perak, s.d., Scortechini, B. 464b (lectotype K [K000895122], designated here).

Notes. Three specimens are listed under the description of Hoya scortechinii: J. Scott s.n. from Penang, B. Scortechinii 464 \& 1557 from Perak. I could only locate B. Scortechinii $464 \mathrm{~b}$ in K. It is a complete and well-preserved specimen bearing a dissection and drawings by Gamble made in November 1906 and is therefore a suitable lectotype.

Hoya sammannaniana A.L.Lamb, Gavrus, Emoi \& Gokusing, Sandakania 19: 77 (2014). - TYPE: Originally from Borneo. Malaysia, Sabah, Beluran, Paitan River, cultivated at Kipandi Park, vouchered on 27 December 2008 as Gokusing, L. in Lamb, A. 1649/2008 (holotype SAN; isotype SNP n.v.).

Hoya sipitangensis Kloppenb. \& Wiberg, Fraterna 15(3): 4 (2002). - TYPE: Originally from Malaysia, Sabah, Sipitang, cultivated in Sweden, Börlange, reputedly vouchered on unknown date as Wiberg, E.K. 52002 (holotype UC, missing). Originally from Malaysia, Sabah (Sarawak sic), Sipitang, 1997, Wiberg, E.K. et al., s.n., cultivated and vouchered in Sweden, Börlange, 2001, Wiberg, E.K. s.n. (neotype UC [UC1784973]).

Hoya yapiana Kloppenb., Gard. Bull. Singapore 61: 327 (2010). - TYPE: Originally from Brunei, Belait, Seria, Tutong District, 21 January 2008, Wang, L.K. 090122, cultivated in Singapore, vouchered on 20 April 2009 as Yap, K.F. s.n. (holotype SING [SING0124341]; isotypes BRUN n.v., K [K000898014]). 
Notes. The type of Hoya sipitangensis was cited as '52002 (UC), collected by EvaKarin Wiberg et al. at Sipitang, Sarawak, Malaysia ex hort. Eva-Karin Wiberg at Börlange, Sweden'. The specimen labelled as holotype of Hoya sipitangensis in UC agrees in collecting information but does not bear the number 52002 which is, in any event, probably a collection date rather than a number as observed for Hoya walliniana and Hoya nyhuusiae. It is barcoded UC1784973. As it is impossible to verify if [UC1784973] is the intended holotype or another specimen obtained from the same plant in cultivation it is designated as neotype of Hoya sipitangensis.

The collection date of the type of Hoya yapiana Kloppenb. is indicated in the protologue as '21 January 2008'; however, this is not the collection date of the specimen but the collection date of a living plant in Brunei that later bloomed in Singapore where it was cultivated by K.F. Yap, who made the type specimen from this plant on 20 April 2009. This collection date is mentioned on the holotype in SING but not on the duplicate in $\mathrm{K}$.

Hoya sigillatis subsp. sigillatis T.Green, Fraterna 17(3): 2 (2004). - TYPE: Originally from Malaysia, Sabah, Tenom Agricultural Park, cultivated in USA, Hawaii, Oahu, Ka'a'awa, vouchered on unknown date as Green, T. 91024 (holotype BISH [BISH1014783]).

Hoya sigillatis T.Green subsp. paitanensis Gavrus, A.L.Lamb, Emoi \& Gokusing, Sandakania 19: 68 (2014). - TYPE: Originally from Malaysia, Sabah, Beluran, Valley of the Paitan River, cultivated at Kipandi Park, vouchered on 10 April 2011 as Gokusing, L. \& Lombika, J. in Lamb, A. 1757/2011 (holotype SAN; isotype SNP n.v.).

Hoya spartioides (Benth.) Kloppenb., Fraterna 14(2): 8 (2001). - Astrostemma spartioides Benth., Hooker's Icon. Pl. 14: 7, t. 1311 (1880). - Absolmsia spartioides (Benth.) Kuntze, Revis. Gen. P1. 2: 418 (1891). - TYPE: Malaysia, North Borneo, 1877-1878, Burbidge, F.W. s.n. (lectotype K [K000894739], designated by Wanntorp \& Forster (2007), first step, designated here, second step; isolectotype K [K000894738]).

Notes. Wanntorp \& Forster (2007) selected Burbidge s.n. (K), a specimen not personally examined by the authors and mounted on two sheets, as lectotype of Hoya spartioides. However the two sheets are not clearly labelled as being part of the same specimen and must therefore be considered as two duplicates following ICN Art. 8.3 (McNeill et al., 2012). The specimen with barcode [K000894739] is therefore designated as the lectotype of Hoya spartioides. Syntype Motley, J. 978 is extant at K [K000894737].

Hoya telosmoides Omlor, Novon 6: 290 (1996). - TYPE: Malaysia, Sabah, Mt Kinabalu, Tenompok, 7 Jun 1932, Clemens, J. \& M.S. 29828 (holotype BM; isotype $\mathrm{K})$.

Hoya undulata S.Rahayu \& Rodda, Gard. Bull. Singapore 67: 86 (2015). - TYPE: Indonesia, West Kalimantan, Putussibau, 300-380 m, on a slope above a stream, February 2014, Sulaiman Hasim s.n. (holotype BO). 
Hoya vacciniiflora O.Schwartz, Mitt. Inst. Bot. Hamburg 7: 261 (1931). - TYPE: Indonesia, Bukit Mulu, 2 December 1924, Winkler, H. 518 (lectotype HBG [HBG506352], designated here).

Notes. Schwartz cited only a single collection for Hoya vacciniiflora O.Schwartz, Winkler 339. One sheet of this collection is present at HBG and is here selected as lectotype.

Hoya verticillata (Vahl) G.Don, Gen. Hist. 4: 128 (1837); Rintz, Malayan Nat. J. 30: 514 (1978); Veldkamp et al., Blumea 40: 427 (1995). - Sperlingia verticillata Vahl, Skr. Naturhist.-Selsk. 6: 113 (1810). - TYPE: Flohr in Hb. Vahl 'ex Ind. Orient. Cynanchum?’ (lectotype C [C10006735], designated by Veldkamp et al., (1995); possible isolectotype C [C10006736]).

Hoya acuta Haw., Revis. P1. Succ. 4 (1821). - TYPE: 'Vidi crescentem sine floribus in region horto Kewense A.D. 1819'; 'Hort Liv 1825' (neotype K, designated here).

Hoya pallida Lindl., Bot. Reg. 11: t. 951 (1826), non Hoya pallida Dalzell \& Gibson (1861). - TYPE: Bot. Reg. 11: t. 951 (1826) (lectotype, designated here). 'Hort Liv 1825' (epitype K, designated here).

Hoya nicobarica R.Br. ex J.Traill, Trans. Hort. Soc. London 7: 28 (1830). - TYPE: India, Nicobar Islands, 1785, Hb. Banks, J.P. Rottler/J.G. Koenig s.n. (lectotype BM [BM001014257], designated by Veldkamp et al. (1995).

Hoya angustifolia J.Traill, Trans. Hort. Soc. London 7: 29 (1830). - Hoya pottsii J.Traill var. angustifolia (J.Traill) Tsiang \& P.T.Li, Acta Phytotax. Sin. 12: 124 (1974). - TYPE: China, Potts (not found, possibly just a living plant).

Hoya pottsii J.Traill, Trans. Hort. Soc. London 7: 25 (1830). - TYPE: China, Macao. Cultivated by Mr. Sabine (lectotype Trans Hort. Soc. London 7, plate 1, designated by Forster \& Liddle (1992c)).

Hoya hookeriana Wight, Contr. Bot. India 37 (1834). - TYPE: Bangladesh, Sylhet, Wall. Asclep 28B [=Wall. Cat. 8158B] HRWP (lectotype K [K000873071], designated here; isolectotypes BM, E [E00179571], K [K001129101], K-W).

Hoya parasitica Wall. ex Wight, Contr. Bot. India 37 (1834); Veldkamp et al., Blumea 40: 427 (1995); Jagtap \& Singh, Fasc. Fl. India 24: 114 (1999). - Asclepias parasitica Roxb., Hort. Bengal. 20 (1814), nom. inval. - Asclepias parasitica Roxb., Fl. Ind. 2: 42 (1832), non Asclepias parasitica Wall. ex Hornem. (1819). - TYPE: Roxburgh illustration number 1382 (lectotype K, designated here [http://apps.kew.org/ floraindica/img/illustration/large/57419.jpg]). 
Hoya opposita (Vahl) G.Don, Gen. Hist. 4: 128 (1838); Veldkamp et al., Blumea 40: 427 (1995). - Sperlingia opposita Vahl, Skr. Naturhist.-Selsk. 6: 114 (1810). - TYPE: Flohr in Hb. Vahl 'ex Ind. Orient.' (lectotype C [C10006734], designated by Veldkamp et al. (1995)).

Hoya ridleyi King \& Gamble, J. Asiat. Soc. Bengal, Pt. 2, Nat. Hist. 74(2): 575 (1908); Rintz, Malayan Nat. J. 30: 514 (1978). - TYPE: Singapore, Grange Road, Ridley, H.N. 10358 (lectotype SING [SING0047800], designated here; isolectotype K, a dissection by Gamble).

Hoya parasitica Wight var. geoffrayi Costantin in Lecomte, Fl. Indo-Chine 4: 136 (1912); Veldkamp et al., Blumea 40: 427 (1995). - TYPE: Cambodia, Campot, 7 April 1904, Geoffray, M 382 (lectotype P [P00639824], designated by Veldkamp et al. (1995)).

Hoya parasitica Wight var. spirei Costantin in Lecomte, Fl. Indo-Chine 4: 136 (1912); Veldkamp et al., Blumea 40: 427 (1995). - TYPE: Laos, Luang Prabang, Dok Than, s.d., Spire 1529 (lectotype P [P00639823], designated by Veldkamp et al. (1995)).

Hoya balansae Costantin in Lecomte, Fl. Indo-Chine 4: 136 (1912). - TYPE: Vietnam, Ha Long Bay, on limestone rocks, 3 July 1885, Balansa, B. 598 (lectotype P [P00645997], designated here).

Hoya globiflora Ridl., J. Fed. Malay States Mus. 5: 164 (1915); Rintz, Malayan Nat. J. 30: 514 (1978) (as 'globifera'); Veldkamp et al., Blumea 40: 427 (1995). - TYPE: Thailand, Surat Thani, Robinson, H.C. 5756 (lectotype SING, designated by Veldkamp et al. (1995) not found; lectotype K, designated here).

Hoya obscurinervia Merr., Philipp. J. Sci. 23: 263 (1923). - TYPE: China, Hainan, San Tsuen, near Nodoa and Loh Hoe, 15 April 1922, McClure, F.A. 9819 (lectotype A [A00076421], designated here; isolectotype IBSC).

Hoya amoena Bakh.f., Blumea 6: 380 (1950) - TYPE: Indonesia, Java, East Java, Beoeki, Poeger, 19 October 1895, Koorders, S.H. 20341 (holotype L [L004312]).

Hoya recurvula Kloppenb., Fraterna 13(4): 9 (2000). - TYPE: Originally from Malaysia? [Southern Malaysia], cultivated in USA, California, Fresno, vouchered in 2000 as Kloppenburg, R.D. 81009 (holotype UC [UC1746636]).

Hoya wibergiae Kloppenb., Fraterna 14(1): 5 (2001). - TYPE: Originally from Philippines, Palawan, Estrella waterfall area, cultivated in USA, California, Fresno, vouchered in 2000 as Kloppenburg, R.D. 951074 (holotype UC [UC1746635]).

Hoya ubudensis Kloppenb. \& Yap, Asklepios 108: 7 (2010). - TYPE: Originally from Indonesia, Bali, Ubud, Tjampuhan, cultivated in Singapore, vouchered on 26 January 2008 as Tay, A. \& Yap, K.F., BAL050208 (holotype SING [SING0143934]). 
Hoya recurvula Kloppenb. subsp. bokorensis Kloppenb. \& Yap, Asklepios 108: 6 (2010). - TYPE: Originally from Cambodia, Kampot, Bokor, cultivated in Singapore, vouchered on 24 August 2008 as Yap, K.F., CBD070101 (holotype SING [SING0143935]).

Hoya bawanglingensis Shao Y.He \& P.T.Li, Novon 19: 357 (2009). - TYPE: China, Hainan Province, Bawangling, $19^{\circ} 07^{\prime} \mathrm{N} 109^{\circ} 06^{\prime} \mathrm{E}$, on tree in montane rainforest, 423 m, 8 August 2007, He, S.H. \& Lin, J.Y. 0708081 (holotype CANT, n.v.; photo MO n.v.).

Hoya amoena Bakh.f. subsp. bogorensis T.Green \& Kloppenb., Hoya New 2(4): 14 (2014) - TYPE: Originally from Indonesia, Java, Bogor Botanic Garden, cultivated in USA, Hawaii, Oahu, Oahu, Ka'a'awa, vouchered in 2014 as Green, T. s.n. (holotype BISH [sheet number 759664]).

Sperlingia tetraphylla nom. nud. annotation on [C10006736].

Hoya albens nom. nud. in Miller, Bristol Nursery Cat. 55 (1826).

Hoya lanceolata Donn, Hort. Cantabrig., ed. 2: 92 (1826), nom. nud. non Hoya lanceolata Wall. ex D.Don (1825).

Notes. The specimen here selected as lectotype of Hoya verticillata was indicated by Veldkamp et al. (1995) as the holotype. This requires a correction to lectotype under ICN Art. 9.9 (McNeill et al., 2012). A possible isotype is present at C [C10006736]. It bears the same annotation on the back of the sheet as the lectotype. However, 'Cynanchum?' has been crossed out and substituted with Sperlingia tetraphylla, a nomen nudum and I therefore doubtfully refer to it as an isotype.

Hoya acuta Haw. was described by Haworth based on a sterile live plant cultivated in Kew 'Vidi crescentem sine floribus in region horto Kewense A.D. 1819'. Following Traill (1830) and Veldkamp et al. (1995), Hoya pallida Lindl., Hoya acuta Haw., and the nomina nuda Hoya lanceolata and Hoya albens, may all represent the same plant, sent as a live specimen to $\mathrm{K}$ by Wallich and then spread to various gardens in the UK. Since no original material is available for Hoya acuta the name is neotypified by a specimen deposited in $\mathrm{K}$ that bloomed in 'Hort Liv' (Liverpool botanic garden?) in 1825 , likely originating from the same Wallich stock.

Hoya pallida Lindl. was likely based on the same live plant as for Hoya acuta (Traill, 1830; Veldkamp et al., 1995) but cultivated in the garden of the Duke of Northumberland. The only original material available is the illustration published in Lindley (1826: 11, t. 951) that is selected as the lectotype. The neotype of Hoya acuta is also selected as an epitype of $H$. pallida. Another specimen, also labelled Hoya pallida that was obtained from cultivation in Chatsworth in 1850, is present in CGE.

The specimen [BM001014257] was indicated as the holotype of Hoya nicobarica R.Br. ex J.Traill in Veldkamp et al. (1995) and is here considered as an effective lectotypification following ICN Art. 9.9 (McNeill et al., 2012). 
Hoya angustifolia J.Traill was possibly based on a live plant and no extant specimens have been found.

Wight indicated the materials for Hoya hookeriana as Wall. Asclep. 28A\&B and Wall. Asclep. n. 39 (ex parte). Following Noltie (2005), the Wallich Catalogue numbers associated with Wall. Asclep. 28A,B are Wall. Cat. 8158A\&B, while Noltie (2005) suggests excluding Wall. Asclep. n. 39 because it is unnamed in the Wallich Cataloge and it does not bear a locality. Wall. Cat. 8153A $(\mathrm{K})$ was incorrectly indicated as the lectotype of Hoya hookeriana Wight by Veldkamp et al. (1995). The specimen here selected as the lectotype belonged to Wight's personal working herbarium, is labelled 'Herb. R. Wight. Prop' and '28B' and bears a description and sketch in Wight's hand. Syntypes (Wall. Cat. 8158A) are to be found at E [E00179570], K [K001129100], [K000873070] and K-W.

Veldkamp et al. (1995) cited a Roxburgh (BM) specimen as the holotype of Hoya parasitica Wall. ex Wight. This counts as an effective lectotypification under ICN Art 9.9 (McNeill et al., 2012). However no Roxburgh specimen identified as Hoya parasitica is present in BM. The only original material is therefore the illustration in $\mathrm{K}$ that is here selected as the lectotype.

Numerous specimens are cited in the protologue of Hoya ridleyi King \& Gamble, collected by Curtis and Ridley. Rintz indicates the type of the taxon as 'Malaysia, Ridley (K)' The only original materials collected by Ridley in K available for Hoya ridleyi are three dissections by Gamble mounted on a single card. Rintz (1978) cannot therefore be considered a first step lectotypification. Ridley 10358 (SING) is instead here selected as lectotype. Other syntypes found are Curtis s.n. [SING121195, SING0121079], Ridley 9476. ([SING0121189], K, dissection by Gamble), Ridley 5519 ([SING0121191], K, dissection by Gamble).

Hoya balansae Costantin was described from material collected by Balansa in Ha Long Bay in Vietnam. The only Balansa specimen from Ha Long Bay labelled Hoya balansae in Costantin's handwriting has been found in P [P00645997] and is a suitable lectotype.

The only collection for Hoya globiflora Ridl. was indicated as 'Koh Pennan No. 5756.' Veldkamp et al. (1995) indicated a SING duplicate as the holotype that would count as an effective lectotypification under ICN Art 9.9 (McNeill et al., 2012). However, the specimen is not extant at SING and it is also not listed in the SING card index suggesting it may never have been present. The $\mathrm{K}$ duplicate is instead here selected as the lectotype for Hoya globiflora.

Hoya obscurinervia Merr. was based on McClure 9819. The duplicate at A [A00076421] is a well-preserved fertile specimen and it is selected as lectotype.

Hoya vitellina Blume, Mus. Bot. 1(3): 45 (1849) - TYPE: Java, West Java, Blume, C.L.?, s.n. (lectotype L [L0004346], designated here; possible isolectotypes BO [BO1869758, BO1869758], U [U1102651]).

Hoya fuscomarginata N.E.Br., Bull. Misc. Inform. Kew 278 (1910). - TYPE: Origin unknown, cultivated at Glasnevin Botanic Gardens, Dublin, 13 April 1910, s. coll. (K holotype [K000449169]). 
Notes. Hoya vitellina Blume was indicated as originating from West Java, without providing any additional specimen information. Miquel (1857: 522) indicated that specimens of the taxon were collected by Blume and Van Hasselt. The only possible material likely collected by Blume is in L [L0004346]. Following Art. 9.12 of the ICN (McNeill et al., 2012) [L0004346] this is to be considered as 'remaining original material' and therefore here selected as lectotype. Three possible duplicates are present in $\mathrm{U}$ and BO. However, due to the lack of information on these sheets it is impossible to verify if they are actual duplicates.

Hoya fuscomarginata N.E.Br.was described from a specimen deposited in $\mathrm{K}$ originating from cultivation at Glasnevin Botanic Gardens, Dublin and originally purchased from Mr Pauwels, who stated that it had been imported with orchids from British Guiana. This is impossible, as no Hoya species is known to occur in the New World. There is only one specimen in K clearly labelled as type in Brown's hand that is therefore a holotype.

Hoya wallichii (Wight) C.M.Burton, Hoyan 18(1:2): 5 (1996); Noltie, Bot. Robert Wight 177 (2005). - Physostelma wallichii Wight, Contr. Bot. India 40 (1834). TYPE: [Herb. R. Wight Prop], 'Wall Asclep. n. 130' (lectotype K [K000449753], designated in Rodda et al., (2016).

Hoya walliniana Kloppenb. \& Nyhuus, Fraterna 16(4): 9 (2003). - TYPE: Originally from Malaysia, Sabah, Sipitang, cultivated in Sweden, Stockholm, vouchered in November 2003 as Nyhuus, T. s.n. (holotype UC [UC1784975]).

Notes. The type of Hoya walliniana was indicated as '112003 (UC) ex hort. Torill Nyhuus Sweden, originally collected in 1997 in Sipitang, Sartawak [sic.], Sabah, Malaysia'. The specimen labelled as holotype in UC agrees in collecting author and provenance but does not bear collection number 112003. The number is here interpreted as a collection date (November 2003) as seen in Hoya kastbergii and Hoya nyhuusiae. The provenance of the plant is Sipitang, a division of the Malaysian state of Sabah, and not Sarawak as alternatively indicated in the type citation. Provenance and date are here updated in the holotype citation.

Hoya waymaniae Kloppenb., Fraterna 1995(2): 8 (1995). - TYPE: Originally from Malaysia, Sabah, cultivated, USA, California, Fresno (holotype UC missing); Indonesia, Kalimantan Timur, surroundings of Long Sungai Barang, 15 October 1992, van Valkenburg J.L.C.H JVV1190 (neotype K, designated here; isoneotypes BO n.v., L [L0200212]).

Notes. The type of Hoya waymaniae Kloppenb. was mentioned in the original publication as 'cultivated at Fresno, CA., USA from clone obtained from the Sydney Botanical Garden by Ted Green in 1988 or there about. Holotype: UC\#11'. In UC the label of the specimen indicated as holotype of $H$. waymaniae reads: 'Pressed specimen prepared 23 April 1997 from material cultivated by Ted Green, cloned from plant in Sydney Botanical Garden which was obtained in 1985 by Ben Wallace from the Tenom Orchid Centre in Sabah, Borneo. Submitted by Dale Kloppenburg, 1999'. No collector 
or collection number is present but the specimen is clearly derived from the original living plant. This specimen cannot be the type as it was collected two years after the description of $H$. waymaniae. Despite originating from the same living plant from which the type was collected, UC1776371 is not a suitable neotype as it is sterile. We select instead a well-preserved fertile specimen of the taxon, van Valkenburg JVV1190 (K) as the neotype.

Hoya wongii Rodda, Simonsson \& L.Wanntorp, Blumea 56: 205 (2011). - TYPE: Brunei, Tutong district, Pasir Puteh, 5 October 1989. Wong, K.M. KMW1566 (holotype BRUN; isotypes K, L, SAN, SING).

\section{Index to the names (accepted names in bold)}

Absolmsia spartioides (Benth.) Kuntze sub: Hoya spartioides (Benth.) Kloppenb. Acanthostemma puberum Blume sub: Hoya pubera Blume Asclepias carnosa Blanco sub: Hoya multiflora Blume Asclepias parasitica Roxb. sub: Hoya verticillata (Vahl) G.Don Astrostemma spartioides Benth. sub: Hoya spartioides (Benth.) Kloppenb.

Centrostemma coriaceum Meisn. sub: Hoya multiflora Blume Centrostemma cyrtoceras Meisn. sub: Hoya multiflora Blume Centrostemma elegans Blume sub: Hoya multiflora Blume Centrostemma laurifolium Blume sub: Hoya multiflora Blume Centrostemma lindleyanum (Decne.) Decne. sub: Hoya multiflora Blume Centrostemma micranthum Blume sub: Hoya multiflora Blume Centrostemma multiflorum (Blume) Decne. sub: Hoya multiflora Blume Centrostemma multiflorum sensu Chun sub: Hoya multiflora Blume Centrostemma platypetalum Merr. sub: Hoya multiflora Blume Clemensiella omlorii Livsh. \& Meve sub: Hoya omlorii (Livsh. \& Meve) L.Wanntorp \& Meve

Cyrtoceras coriaceum Heynh. sub: Hoya multiflora Blume

Cyrtoceras elegans (Blume) Miq. sub: Hoya multiflora Blume

Cyrtoceras floribundum Maund sub: Hoya multiflora Blume

Cyrtoceras laurifolium (Blume) Miq. sub: Hoya multiflora Blume

Cyrtoceras lindleyanum Decne. sub: Hoya multiflora Blume

Cyrtoceras micranthum (Blume) Miq. sub: Hoya multiflora Blume

Cyrtoceras multiflorum (Blume) Heynh. sub: Hoya multiflora Blume

Cyrtoceras reflexum Benn. sub: Hoya multiflora Blume Cyrtoceras uncinatum Teijsm. \& Binn. sub: Hoya multiflora Blume

Eriostemma obtusifolioides Gilding \& T.Green sub: Hoya coronaria Blume

Hiepia corymbosa V.T. Pham \& Aver. sub: Hoya ignorata T.B.Tran, Rodda, Simonsson \& Joongku Lee

Hoya acicularis T.Green \& Kloppenb.

Hoya acuta Haw. sub: Hoya verticillata (Vahl) G.Don

Hoya aeschynanthoides Schltr.

Hoya albens nom. nud. sub: Hoya verticillata (Vahl) G.Don 
Hoya amoena Bakh.f. sub: Hoya verticillata (Vahl) G.Don

Hoya amoena Bakh.f. subsp. bogorensis T.Green \& Kloppenb. sub: Hoya verticillata

(Vahl) G.Don

Hoya angustifolia J.Traill sub: Hoya verticillata (Vahl) G.Don

Hoya angustisepala Elmer ex C.M.Burton sub: Hoya coriacea Blume

Hoya australis R.Br. ex J.Traill

Hoya bakoensis Rodda

Hoya balansae Costantin sub: Hoya verticillata (Vahl) G.Don

Hoya bawanglingensis Shao Y.He \& P.T.Li sub: Hoya verticillata (Vahl) G.Don

Hoya beccarii Rodda \& Simonsson

Hoya benchaii Gavrus, A.L.Lamb, Emoi \& Gokusing

Hoya brunoniana Wight sub: Hoya coriacea Blume

Hoya callistophylla T.Green

Hoya caudata Hook.f.

Hoya caudata Hook.f. var. crassifolia Ridl. sub: Hoya caudata Hook.f.

Hoya celebica Boerl. sub: Hoya multiflora Blume

Hoya chewiorum A.L.Lamb, Gavrus, Emoi \& Gokusing

Hoya brunoniana Wight sub: Hoya coriacea Blume

Hoya clemensiorum T.Green

Hoya coriacea Blume

Hoya coriacea sensu Lindley sub: Hoya multiflora Blume

Hoya coronaria Blume

Hoya corymbosa Rodda \& Simonsson

Hoya crassifolia Ridl. sub: Hoya caudata Hook.f.

Hoya crassipes Turcz. sub: Hoya diversifolia Blume

Hoya cumingiana Decne.

Hoya curtisii King \& Gamble

Hoya danumensis Rodda \& Nyhuus

Hoya devogelii Rodda \& Simonsson

Hoya diversifolia Blume

Hoya diversifolia Blume subsp. el-nidicus (Kloppenb.) Kloppenb. sub: Hoya diversifolia Blume

Hoya el-nidicus Kloppenb. sub: Hoya diversifolia Blume

Hoya elegans sensu (Blume) Boerl. sub: Hoya multiflora Blume

Hoya elliptica Hook.f.

Hoya elmeri Merr.

Hoya esculenta Tsiang sub: Hoya diversifolia Blume

Hoya fauziana Rodda, Simonsson \& A.L.Lamb

Hoya finlaysonii Wight

Hoya forbesii King \& Gamble

Hoya fraterna Blume sub: Hoya coriacea Blume

Hoya fuscomarginata N.E.Br. sub: Hoya vitellina Blume

Hoya gildingii Kloppenb.

Hoya glabra Schltr.

Hoya globiflora Ridl. sub: Hoya verticillata (Vahl) G.Don

Hoya hamiltoniorum A.L.Lamb, Gavrus, Emoi \& Gokusing 
Hoya heterophylla nom. nud. sub: Hoya diversifolia Blume

Hoya hookeriana Wight sub: Hoya verticillata (Vahl) G.Don

Hoya ignorata T.B.Tran, Rodda, Simonsson \& Joongku Lee

Hoya imperialis Lindl.

Hoya imperialis Lindl. var. rauschii Regel sub: Hoya imperialis Lindl.

Hoya javanica Boerl. sub: Hoya multiflora Blume

Hoya jiewhoeana Rodda, A.L.Lamb \& Gokusing

Hoya kastbergii Kloppenb.

Hoya kipandiensis Gavrus, A.L.Lamb, Emoi \& Gokusing

Hoya kloppenburgii T.Green

Hoya lacunosa Blume

Hoya Iambii T.Green

Hoya lanceolata nom. nud. sub: Hoya verticillata (Vahl) G.Don

Hoya lasiantha (Korth. ex Blume) Miq.

Hoya latifolia (Wight) G.Don

Hoya liangii Tsiang sub: Hoya diversifolia Blume

Hoya linusii A.L.Lamb, Gavrus \& Emoi sub: Hoya phyllura O.Schwartz

Hoya macrophylla Wight sub: Hoya latifolia (Wight) G.Don

Hoya mappigera Rodda \& Simonsson

Hoya medinillifolia Rodda \& Simonsson

Hoya meredithii T.Green

Hoya mindanaensis Elmer sub: Hoya coriacea Blume

Hoya mindorensis Schltr.

Hoya mindorensis subsp. superba Kloppenb. sub: Hoya elmeri Merr.

Hoya minutiflora Rodda \& Simonsson

Hoya mitrata Kerr

Hoya monetteae T.Green

Hoya multiflora Blume

Hoya nabawanensis Kloppenb. \& Wiberg

Hoya nicobarica R.Br. ex J.Traill sub: Hoya verticillata (Vahl) G.Don

Hoya nuttiana Rodda \& Simonsson

Hoya nyhuusiae Kloppenb.

Hoya obscura Elmer ex C.M.Burton

Hoya obscura Elmer sub: Hoya obscura Elmer ex C.M.Burton

Hoya obscurinervia Merr. sub: Hoya verticillata (Vahl) G.Don

Hoya obtusifolia Wight

Hoya occlusa Ridl. sub: Hoya coriacea Blume

Hoya omlorii (Livsh. \& Meve) L.Wanntorp \& Meve

Hoya opposita (Vahl.) G.Don sub: Hoya verticillata (Vahl) G.Don

Hoya orbiculata Wall. ex Wight \& Arn. sub: Hoya diversifolia Blume

Hoya pallida Lindl. sub: Hoya verticillata (Vahl) G.Don

Hoya parasitica Wall. ex Wight sub: Hoya verticillata (Vahl) G.Don

Hoya parasitica Wight var. geoffrayi Costantin sub: Hoya verticillata (Vahl) G.Don

Hoya parasitica Wight var. spirei Costantin sub: Hoya verticillata (Vahl) G.Don

Hoya persicinicoronaria Shao Y.He \& P.T.Li sub: Hoya diversifolia Blume

Hoya phyllura O.Schwartz 
Hoya plicata King \& Gamble subsp. rundumensis T.Green sub: Hoya rundumensis

(T.Green) Rodda \& Simonsson

Hoya pottsii J.Traill sub: Hoya verticillata (Vahl) G.Don

Hoya pottsii J.Traill var. angustifolia Tsiang \& P.T.Li sub: Hoya verticillata (Vahl) G.Don

Hoya pubera Blume

Hoya ranauensis T.Green \& Kloppenb.

Hoya recurvula Kloppenb. sub: Hoya verticillata (Vahl) G.Don

Hoya recurvula Kloppenb. subsp. bokorensis Kloppenb. \& Yap sub: Hoya verticillata

(Vahl) G.Don

Hoya refracta nom. nud. sub: Hoya multiflora Blume

Hoya reticulata Costantin sub: Hoya multiflora Blume

Hoya retrorsa Gavrus, A.L.Lamb, Emoi, Gokusing

Hoya revoluta Wight ex Hook.f.

Hoya ridleyi King \& Gamble sub: Hoya verticillata (Vahl) G.Don

Hoya rintzii Rodda, Simonsson \& S. Rahayu

Hoya rundumensis (T.Green) Rodda \& Simonsson

Hoya ruthiae Rodda

Hoya sammannaniana A.L.Lamb, Gavrus, Emoi, Gokusing

Hoya scortechinii King \& Gamble

Hoya sigillatis T.Green subsp. sigillatis

Hoya sigillatis T.Green subsp. paitanensis Gavrus, A.L.Lamb, Emoi, Gokusing

Hoya sipitangensis Kloppenb. \& Wiberg

Hoya spartioides (Benth.) Kloppenb.

Hoya telosmoides Omlor

Hoya teysmanniana Miq. sub: Hoya obtusifolia Wight

Hoya ubudensis Kloppenb. \& Yap sub: Hoya verticillata (Vahl) G.Don

Hoya undulata S.Rahayu \& Rodda

Hoya vacciniiflora $\mathrm{O}$.Schwartz

Hoya verticillata (Vahl) G.Don

Hoya vitellina Blume

Hoya wallichii (Wight) C.M.Burton

Hoya walliniana Kloppenb. \& Nyhuus

Hoya waymaniae Kloppenb.

Hoya wibergiae Kloppenb. sub: Hoya verticillata (Vahl) G.Don

Hoya wongii Rodda, Simonsson \& L. Wanntorp

Hoya yapiana Kloppenb. sub: Hoya sipitangensis Kloppenb. \& Wiberg

Hoya zollingeriana Miq. sub: Hoya diversifolia Blume

Otostemma lacunosum (Blume) Blume sub: Hoya lacunosa Blume

Physostelma wallichii Wight sub: Hoya wallichii (Wight) C.M.Burton

Plocostemma lasianthum Korth ex Blume sub: Hoya lasiantha (Korth. ex Blume)

Miq.

Sperlingia opposita Vahl sub: Hoya verticillata (Vahl) G.Don

Sperlingia tetraphylla nom. nud. sub: Hoya verticillata (Vahl) G.Don

Sperlingia verticillata Vahl sub: Hoya verticillata (Vahl) G.Don 
ACKNOWLEDGEMENTS. This study is part of an on-going research project on the systematics of Asian Apocynaceae. Financial support was received from the National Parks Board (Singapore) which sponsored numerous herbarium study trips to Asian and European institutions. The curators of A, BISH, BM, BO, BRUN, CGE, E, FI, G, HITBC, HN, IBSC, K, KEP, KUN, L, OXF, P, SAN, SAR, SING, SNP, TO, UC, US, VN, WRSL and Z herbaria are thanked for allowing access and/or for allowing loans or high quality images of herbarium specimens. The librarians of the Singapore Botanic Gardens, Royal Botanic Gardens Kew and Royal Botanic Garden Edinburgh have helped to find often obscure references. Elisabeth Liljebjörn spent many hours scanning all the issues of the journals Fraterna and Hoyan as well as creating PDFs of numerous papers. Lastly Anthony Lamb and Anthea Phillips are thanked for their continuous support for my work on Bornean Hoya.

\section{References}

Bennett, J.J. (1838) Plantae Javanicae Rariores Part 1, page [1]-104. London: H. Allen et socios.

Blume, C.L. (1823). Catalogus. Batavia: Lands Drukkerji

Blume, C.L. (1826). Bijdragen tot de Flora van Nederlandsch Indie, vol. 16. Batavia: Lands Drukkerji.

Blume, C.L. (1849). Rumphia, vol. 4. Leiden, Amsterdam: C.G. Sulpke.

Backer, C.A. \& Bakhuizen van den Brink, R.C. (1965). Hoya In: Flora of Java, vol. 2, pp. 266-271. Noordhoff, Groningen: Noordhoff.

Bentham, G. (1880). Astrostemma spartioides Benth. In: Hooker, J.D. (ed) Hooker's Icones Plantarum, vol. 14, pp. 7-8, t. 1311. London: Williand and Norgate.

Decaisne, J. (1844) Hoya In: Candolle, A.L.P.P. de (ed) Prodromus Systematis Naturalis Regni Vegetabilis, vol. 8. Paris: Fortin, Masson et sociorum.

Forster, P.I. (1991). Clarification of the author citations, publication places and types for recently described Hoya species (Asclepiadaceae) from the Philippines. Asklepios 5: 100-101.

Forster, P.I. \& Liddle, D.J. (1991). Variation in Hoya australis R.Br ex Traill (Asclepiadaceae). Austrobaileya 3: 503-521.

Forster, P.I. \& Liddle, D.J. (1992a). Asclepiad Profile no. 2. Asklepios 56: 24-26.

Forster, P.I. \& Liddle, D.J.(1992b). Taxonomic studies on the genus Hoya R.Br. (Asclepiadaceae) in Papuasia 4. Typification and synonymy of Hoya revoluta Wight ex J.D. Hook. Austrobaileya 3: 638-639.

Forster, P.I. \& Liddle, D.J. (1992c). Synonymy of Hoya pottsii Traill. Austrobaileya 3: 635.

Hill, K.D. (1988). A revision of Hoya (Asclepiadaceae) in Australia. Telopea 3(2): 241-255.

King, G. \& Gamble, J. (1908). Hoya. In: Flora of the Malayan Peninsula, J. Asiat. Soc. Bengal, Pt. 2. Natural History. 74: 559-580.

Kleijn, D. \& Van Donkelaar, R. (2001). Notes on the taxonomy and ecology of the genus Hoya (Asclepiadaceae) in Central Sulawesi. Blumea 46: 457-483.

Kloppenburg, R.D. (2012). Two new hoyas by Dale Kloppenburg: Hoya samarensis \& Hoya australis ssp. nathalieae. Asklepios 113: 27-29.

Lamb, A. \& Rodda, M. (2016). A Guide to Hoyas of Borneo. Kota Kinabalu: Natural History Publications Borneo.

Lamb, A., Gavrus, A., Emoi, B. \& Gokusing, L. (2014). The hoyas of Sabah, a commentary with seven new species and a new subspecies. Sandakania 19: 1-89.

Liddle, D.J. \& Forster, P.I. (2008). Notes on some commonly cultivated Hoya species from Australia, Papuasia and Melanesia: Hoya australis R.Br. ex Traill. Asklepios 102: 3-15.

Lindley, J. (1826). Hoya pallida. Bot. Reg. 11: t. 951. 
Lindley, J. (1839). Hoya coriacea. Edwards's Bot. Reg. 25: t.18.

Lindley, J. (1846). New garden plant. Hoya imperialis. Edwards's Bot. Reg. 32: t. 68.

Lucas, A.M. (2008). Disposing of John Lindley's library and herbarium: the offer to Australia. Arch. Nat. Hist. 35(1): 15-70.

McNeill, J., Buck, W.R., Demoulin, V., Greuter, W., Hawkworth, D.L., Herendeen, P.S., Knapp, S., Marhold, K., Prado, J., Prud'homme van Reine, W.F., Smith, G.F., Wiersema, J.H. \& Turland, N.J. (2012). International Code of Nomenclature for algae, fungi, and plants (Melbourne Code). Regnum Vegetabile 154. Königstein: Koeltz Scientific Books.

Merrill, E.D. (1918). Species Blancoanae. Manila: Manila Bureau of Printing.

Merrill, E.D. (1921). A bibliographic enumeration of Bornean plants. J. Straits Branch Roy. Asiat. Soc., Special Number. Singapore: Fraser \& Neave Ltd.

Miquel, F.E.W. (1857). Flora van Nederlandsch Indie, vol. 2. Amsterdam: C. G. van der Post.

Nicholas, A. (1992). The Asclepiadaceous works of Rudolf F. Schlechter (1872-1925). Willdenowia 22: 215-264.

Noltie, H.J. (2005). The Botany of Robert Wight. Regnum Vegetabile, vol. 145. Ruggell: A.R.G. Gantner Verlag.

Nutt, P. (2001). Checkliste der Gattung Hoya auf Borneo (Apocynaceae-Asclepiadoideae). Diploma thesis, Westfälische Wilhelms-Universität Münster.

Rahayu, S., Meve, U. \& Rodda, M. (2015). Hoya undulata (Apocynaceae, Asclepiadoideae), a new myrmecophytic species from Borneo, and typification of H. darwinii. Gard. Bull. Singapore 67(1): 85-94.

Rintz, R.E. (1978). The Peninsular Malaysian species of Hoya (Asclepiadaceae). Malayan Nat. J. 30: 467-522.

Rodda, M. (2012). (2074) Proposal to conserve the name Hoya mitrata against $H$. wallichiana (Apocynaceae, Asclepiadoideae). Taxon 61: 685-686.

Rodda, M. (2015a). Two new species of Hoya R.Br. (Apocynaceae, Asclepiadoideae) from Borneo. PhytoKeys 53: 83-93.

Rodda, M. (2015b). A new typification of Hoya zollingeriana (Apocynaceae, Asclepiadoideae). Gard. Bull. Singapore 67(2): 305-307.

Rodda, M. \& Ercole, E. (2014). Hoya papaschonii (Apocynaceae: Asclepiadoideae), a new species from southern Thailand with a peculiar corona. Phytotaxa 175(2): 97-106.

Rodda, M. \& Simonsson, N. (2011a). Hoya devogelii (Apocynaceae: Asclepiadoideae), a new species from Sarawak, Borneo. Webbia 66(1): 33-38.

Rodda, M. \& Simonsson, N. (2011b). Hoya medinillifolia (Apocynaceae: Asclepiadoideae), a new species from lowland forest of Sarawak, Borneo. Webbia 66(2): 149-154.

Rodda, M. \& Simonsson Juhonewe, N. (2013a). Hoya nuttiana (Apocynaceae: Asclepiadoideae), a new species from Sarawak, Malaysian Borneo. Phytotaxa 140(1): 56-60.

Rodda, M. \& Simonsson Juhonewe, N. (2013b). The taxonomy of Hoya micrantha and Hoya revoluta (Apocynaceae, Asclepiadoideae). Webbia 68: 7-16.

Rodda, M., Simonsson Juhonewe, N. \& Ercole, E. (2014). Hoya corymbosa (Apocynaceae: Asclepiadoideae), a new unusual species from Sabah, Borneo and its systematic position based on phylogenetic analyses. Syst. Bot. 38: 1125-1131.

Rodda, M., Simonsson Juhonewe, N. \& Middleton, D.J. (2016). The taxonomic status of the presumed extinct Singaporean Hoya wallichii (Apocynaceae: Asclepiadoideae). Gard. Bull. Singapore 68: 175-187.

Rumphius, G.E. (1747). Herbarium amboinense, vol. 4. Amsterdam: Apud Fransicum Changuion, Joannem Catuffe, Hermannum Uytwerf.

Smith, A.C. (1988). Hoya. In: Flora Vitiensis Nova, A New Flora of Fiji, vol. 4, pp. 116-123. Honolulu: SB Printers Inc. 
Schlechter, R. (1908). Beiträge zur Kenntnis der Asclepiadaceen des Monsum-Gebietes. Bot. Jahrb. Syst. 40 (Beibl. 92): 1-45.

Stafleu, F.A. (1970). Benjamin Delessert and Antoine Lasègue. Taxon 19: 920-936.

Stafleu, F.A. \& Cowan, R.S. (1976). Taxonomic Literature 1, 2nd ed. Utrecht: Bohn, Scheltema \& Holkema.

Stearn, W.T. (2008). Botanical Latin. Singapore: KHL Printing Co.

Traill, J. (1830). Accounts and descriptions of the several plants belonging to the genus Hoya which are cultivated in the garden of the Horticultural Society at Chiswick. Trans. Hort. Soc. London 7: 16-30.

Van Steenis-Kruseman, M.J. (1950). Malaysian plant collectors and collections: Being a cyclopaedia of botanical exploration in Malaysia and a guide to the concerned literature up to the year 1950. In: Flora Malesiana, Ser. 1, Spermat. 1, pp. 5-606. Jakarta: P.Noordhoff-Kolff N.V.

Veldkamp, J.F., van Donkelaar, R. \& Kloppenburg, R.D. (1995). The identity of Sperlingia Vahl (Asclepiadaceae). Blumea 40: 425-428.

Wanntorp, L. \& Forster, P.I. (2007). Phylogenetic relationships between Hoya and the monotypic Genera Madangia, Absolmsia, and Micholitzia (Apocynaceae, Marsdenieae): Insights from flower morphology. Ann. Missouri Bot. Gard. 94: 36-55.

Wanntorp, L., Kocyan, A. \& Renner, S.S. (2006a). Wax plants disentangled: a phylogeny of Hoya (Marsdenieae, Apocynaceae) inferred from nuclear and chloroplast DNA sequences. Molec. Phylogenet. Evol. 39: 722-733.

Wanntorp, L., Kocyan, A., van Donkelaar, R. \& Renner, S.S. (2006b). Towards a monophyletic Hoya (Marsdenieae, Apocynaceae): inferences from the chloroplast trnL region and the rbcL-atpB spacer. Syst. Bot. 31: 586-596.

Wanntorp, L., Gotthardt, K. \& Muellner, A.N. (2011). Revisiting the wax plants (Hoya, Marsdenieae, Apocynaceae): Phylogenetic tree using the matK gene and psbA-trnH intergenic spacer. Taxon 60: 4-14.

Wanntorp, L., Grudinski, M., Forster, P.I., Muellner-Riehl, A.N. \& Grimm, G.W. (2014). Wax plants (Hoya, Apocynaceae) evolution: Epiphytism drives successful radiation. Taxon 63: 89-102.

Wight, R. (1834). Contributions to the botany of India. London: Parbury, Allen \& Co. 
